\title{
The cumulative impacts of small reservoirs on hydrology: a review
}

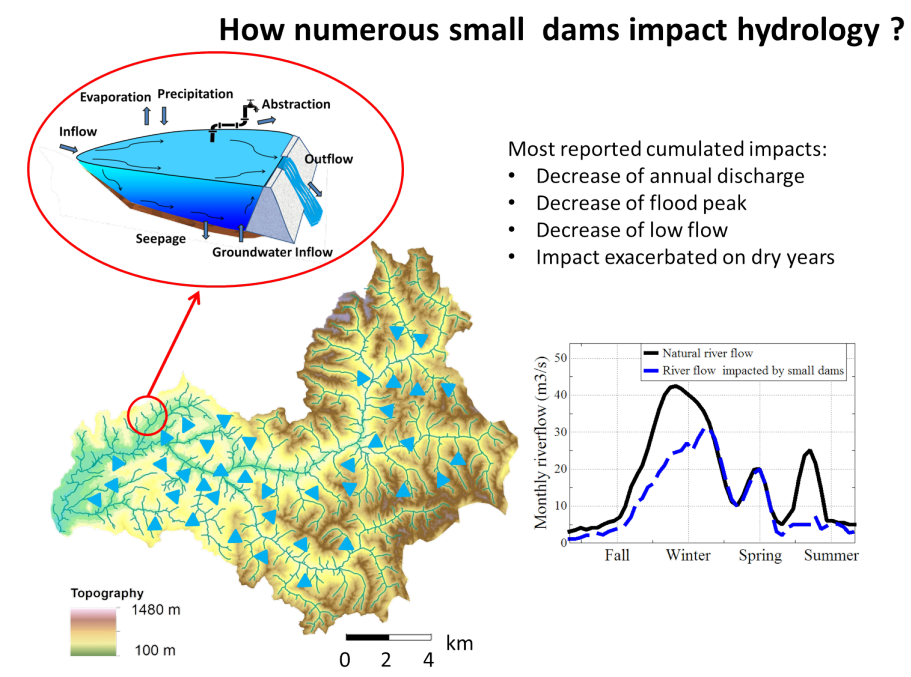

\section{Highlights}

- The number of small dams is still increasing and is approaching 39 dams per square kilometre

- Small dams lead to a decrease in annual stream discharge of $13 \% \pm 8 \%$

- Cumulative impacts cannot be estimated using simple indicators

- Cumulative impacts are difficult to estimate and are most often quantified from modelling

- The lack of information on small reservoir characteristics is a real shortcoming for properly estimating their cumulative impacts

Email addresses: florence.habets@upmc.fr (Habets Florence), jerome.molenat@inra.fr (Molénat Jérôme ) 


\title{
The cumulative impacts of small reservoirs on hydrology: a review
}

\author{
Habets Florence ${ }^{\mathrm{a}, *}$, Molénat Jérôme ${ }^{\mathrm{b}, *}$, Carluer Nadia $^{\mathrm{c}}$, Douez Olivier ${ }^{\mathrm{d}}$, Leenhardt Delphine \\ ${ }^{a}$ CNRS/Sorbonne Université, UMR 7619 Metis, Paris, France \\ ${ }^{b}$ UMR LISAH, Univ Montpellier, INRA, IRD, Montpellier SupAgro, Montpellier, France \\ ${ }^{c}$ Irstea, UR RiverLy, centre de Lyon-Villeurbanne, 69625 Villeurbanne, France \\ ${ }^{d}$ BRGM, Bordeaux, France \\ ${ }^{e}$ Toulouse Univ, INRA, INPT, INP EI PURPAN, AGIR, Castanet Tolosan, France
}

\begin{abstract}
The number of small reservoirs has increased due to their reduced cost, the availability of many favourable locations, and their easy access due to proximity. The cumulative impacts of such small reservoirs are not easy to estimate, even when solely considering hydrology, which is partially due to the difficulty in collecting data on the functioning of such reservoirs. However, there is evidence indicating that the cumulative impacts of such reservoirs are significant.

The aim of this article is to present a review of the studies that address the cumulative impacts of small reservoirs on hydrology, focusing on the methodology and on the way in which these impacts are assessed.

Most of the studies addressing the hydrological cumulative impacts focused on the annual stream discharge, with decreases ranging from $0.2 \%$ to $36 \%$ with a mean value of $13.4 \% \pm 8 \%$ over approximately 30 references. However, it is shown that similar densities of small reservoirs can lead to different impacts on stream discharge in different regions. This result is probably due to the hydro-climatic conditions and makes defining simple indicators to provide a first guess of the cumulative impacts difficult. The impacts also vary in time, with a more intense reduction in the river discharge during the dry years than during the wet years. This finding is certainly an important point to take into consideration in the context of climate change.

Two methods are mostly used to estimate cumulative impacts: i) exclusively data-based methods and ii) models. The assumptions, interests and shortcomings of these methods are presented. Scientific tracks are proposed to address the four main shortcomings, namely the estimation of the associated uncertainties, the lack of knowledge on reservoir characteristics and water abstraction and the accuracy of the impact indicators.
\end{abstract}




\section{Introduction}

Large reservoirs have strong impacts on hydrology at regional to global scales. Indeed, it was estimated that such large reservoirs have led to a global runoff decrease of approximately $2 \%$ (Biemans et al., 2011), to a sea level decrease of approximately $30 \mathrm{~mm}$ (Chao et al., 2008), and that they store a volume equivalent to approximately $10 \%$ of the natural annual soil storage capacity at the global scale (Zhou et al., 2016). However, these studies did not consider the impacts of smaller reservoirs on hydrology. Downing (2010) found that small ponds and lakes (smaller than $0.1 \mathrm{~km}^{2}$ ) cover a larger area and are more numerous than large reservoirs and that approximately $10 \%$ of them are constructed reservoirs.

When considered individually, each reservoir may modify its local and remote environment. The cumulative impacts of many reservoirs in a catchment are the modifications induced by a set of reservoirs (or reservoir network) taken as a whole. The cumulative impacts are not necessarily the sum of individual modifications because reservoirs may be inter-dependent, such as cascading reservoirs along a stream course. Cumulative impacts are not the simple addition of individual impacts: they can develop via an additive or incremental process, a supra-additive process (where the cumulative effect is greater than the sum of the individual effects) or an infra-additive process (where the cumulative effect is less than the sum of the individual effects). The total impact is therefore equal to the sum of the impacts of the developments and to interaction effects. Indeed, addressing the cumulative impacts implies covering different spatial and temporal scales (Canter and Kamath, 1995) and having a reference state (McCold and Saulsbury, 1996). The cumulative impacts of small reservoirs on sediment transport, biochemistry, ecology and greenhouse gas emissions have been studied (Berg et al., 2016; Mbaka and Wanjiru Mwaniki, 2015; Downing, 2010; Poff and Zimmerman, 2010; St. Louis et al., 2000), as have the impacts of such reservoirs on hydrology (Nathan and Lowe, 2012; Fowler et al., 2015). The reported impacts are generally strong but present a large variation.

Estimating the cumulative impacts of systems of small reservoirs on a given basin has become an issue as their number increases (for instance, a 3\% increase per year in the US (Berg et al., 2016)). This trend may persist because these systems are often considered to be a technique to

\footnotetext{
*The authors contributed equally

Email addresses: florence.habets@upmc.fr (Habets Florence), jerome.molenat@inra.fr (Molénat Jérôme )
} 
adapt to climate change (van der Zaag and Gupta, 2008). Indeed, small reservoirs are mainly used to store water during the wet season to support water use during the dry season, particularly for irrigation and livestock in rural areas (Wisser et al., 2010; Nathan and Lowe, 2012); to store water during storms to prevent flooding; or to store sediments in check dams to reduce erosion and muddy flood risks. Because the part of the global population that will experience water scarcity is projected to increase with climate change and because the intensity of storm events is also projected to simultaneously increase (Pachauri et al., 2014), there is increasing pressure to construct small reservoirs (van der Zaag and Gupta, 2008; Thomas et al., 2011).

However, an uncontrolled development of such small reservoirs may increase the water resource problem in both quantitative and qualitative ways. Thus, water managers are seeking some indicators that would help to determine optimal networks of small reservoirs in terms of storage capacities and in terms of locations and management. Consequently, in France, the Ministry of the Environment requested a joint scientific assessment to collect useful information/knowledge and tools to provide local stakeholders with such indicators and methods to assess the cumulative impacts of small reservoirs. This request led to a review covering biochemistry, ecology, hydrology and hydromorphology (Carluer et al., 2016). In this paper, a full review of the cumulative impacts of small reservoirs on hydrology is presented because the hydrological impact will affect the other impacts. Although there is no accepted definition of small reservoirs, it is commonly accepted that the storage capacities of such reservoirs are below 1 million $\mathrm{m}^{3}$, as stated by Ayalew et al. (2017) and Thomas et al. (2011). This review does not extend to the very small reservoirs of few hundreds of $m^{3}$ that can be used for water harvesting (Lasage and Verburg, 2015).

First, a synthesis of the quantification of the impacts at the basin scale is presented, and the ability of some conventional descriptors to be used as indicators is studied. Then, the various ways in which small reservoirs can impact the water cycle are presented, along with the methods that are used in the literature to estimate the cumulative impacts of such numerous and not always well-known structures. These results are then discussed, addressing the uncertainties, long-term trends, and impacts on other biochemical, ecological and social components.

\section{Evidence of the impacts of small reservoirs on hydrology}

From the literature review, the cumulative impacts of small reservoirs on hydrology are most often estimated from the annual discharge, low flows and floods. There is a general consensus 
that sets of small reservoirs lead to a reduction in the flood peaks (Frickel, 1972; Galea et al., 60 2005; Nathan and Lowe, 2012; Thompson, 2012; Ayalew et al., 2017) of up to 45\%, particularly 61 since some reservoirs are constructed as stormwater retention ponds (Fennessey et al., 2001; 62 Del Giudice et al., 2014). However, over-topping flooding or dam failure can result in large 63 floods (Ayalew et al., 2017), which may lead to casualties including death (Tingey-Holyoak, 64 2014). Such failures can be more frequent for small dams than for larger dams due to the lack of 65 adapted policies, which may lead to a lack of maintenance and a tendency to store excess water 66 to secure production (Pisaniello, 2010; Camnasio and Becciu, 2011; Tingey-Holyoak, 2014).

The low flows are also frequently reported to decrease when a set of small reservoirs is

Lowe, 2012; Thompson, 2012) with a large spread (0.3 to 60\%), although the water stored can occasionally be used to sustain a low flow (Thomas et al., 2011). The majority of studies have focused on the annual stream discharge, reporting a decrease in the mean annual discharge that ranges from $0.2 \%$ (Hughes and Mantel, 2010) to 36\% (Meigh, 1995). On average, in approximately 30 references, the decrease in the mean annual discharge reaches $13.4 \% \pm 8 \%$ (Figure 1 and Appendix Table A.1)
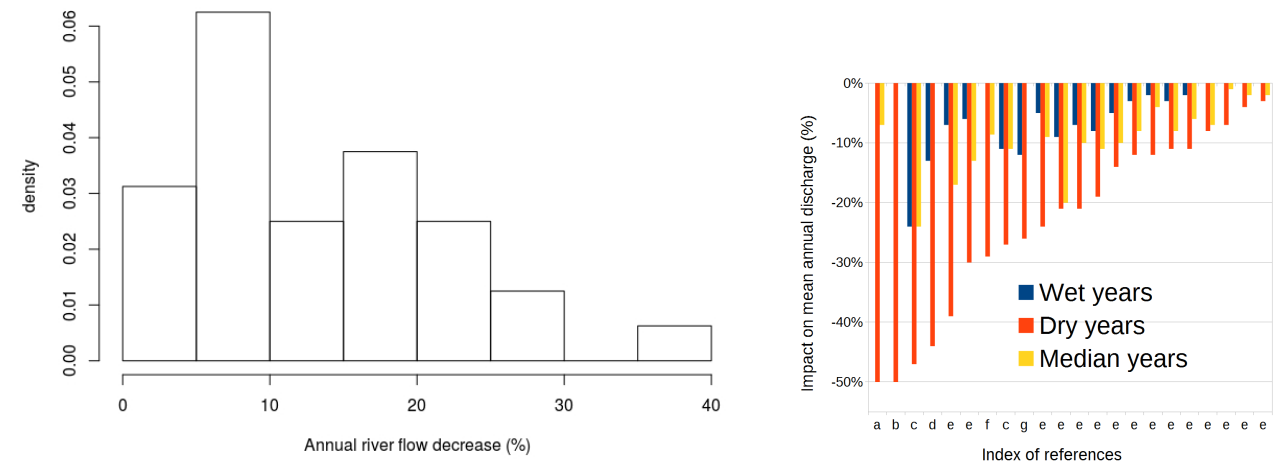

Figure 1: Left: Distribution of the estimated annual stream discharge decrease attributed to reservoir networks. The distribution is established based on 20 values. Right: Impact on the annual discharge estimated during wet, median and dry years. Each bar corresponds to a different catchment. The estimations are from the following references: a: Gutteridge-Haskins-Davey (1987), b: Ockenden and Kotwicki (1982), c: Dubreuil and Girard (1973), d: Cresswell (1991), e: Teoh (2003), f: Habets et al. (2014), and g: Kennon (1966).

The right part of Figure 1 shows that the impacts on annual flows are not constant from year to year but tend to be lower during the wet years and two times greater than the median impact 
in the driest years. This result is very important because it indicates that even without changing the small reservoir network, its impacts will change in the context of climate change: it may decrease in areas that will become wetter but may increase in areas that will become drier.

One key issue in estimating the cumulative impacts is understanding how such impacts are related to the reservoir network, i.e., the level at which the basin is equipped with small dams to avoid over-equipping the basin, with consequences in terms of economy and ecology. Having a single indicator or a set of indicators capable of estimating the cumulative impacts of small reservoirs on the mean annual discharge would be helpful to most water management agencies. Based on the estimated values collected in the literature, a preliminary analysis was performed to determine whether some easy-to-access properties of the reservoir network could be used as indicators. For this purpose, we collected the main characteristics of the basins and of their small reservoir network from the available studies and attempted to connect them to the impacts on the mean annual discharge. We used the reservoir's density, expressed as the number of reservoirs per square kilometre or as the volume stored per square kilometre, and the mean precipitation or the mean discharge in the basin. The results presented in Figure 2 show that none of these characteristics are able to be used as indicators for such contrasted basins as the ones found in the literature. Indeed, within a narrow range of specific discharge or precipitation, the decrease of the annual discharge varies a lot and can not be correlated to the density of reservoir network. A more regional-scale view could be useful to attempt to disentangle different types of climate or use. However, according to the sample of available studies, only a continental-scale analysis was possible. It appears from these figures that the general characteristics present a wider spread between continents than within a given continent, even if the results are from different studies. For instance, the specific discharge is low in Australia, the density is low in Africa, and the storage volume tends to be important in America. However, even within a continent, these characteristics are not sufficiently well linked to the impacts to be reliably used as indicators.

This result occurs because the cumulative impacts of reservoir networks rely on a large number of factors: the hydrological processes occurring in each reservoir, the water management (water abstraction rate and timing, water uptakes from and releases to the river), the reservoir characteristics, the reservoir network geometry, and the connectivity of each reservoir to the stream drainage network. These points are detailed below. 


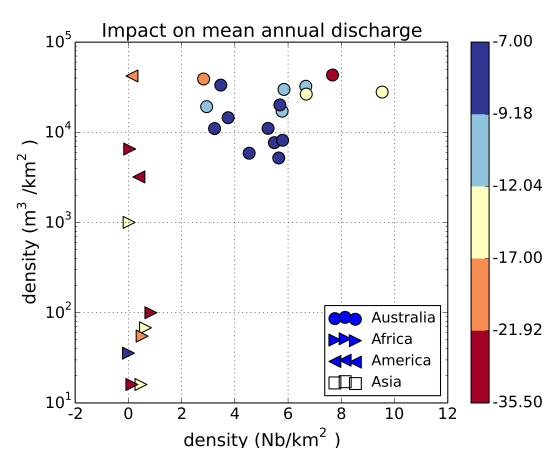

(a)

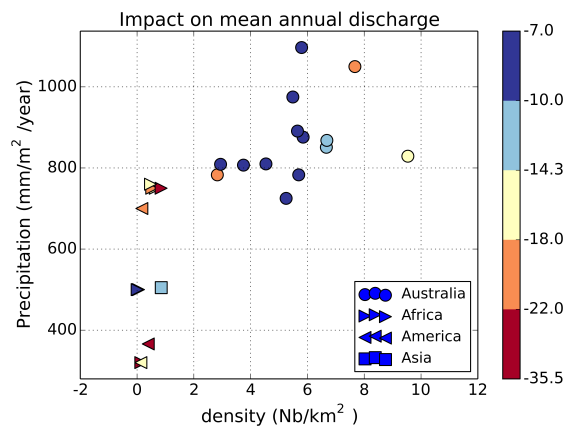

(b)

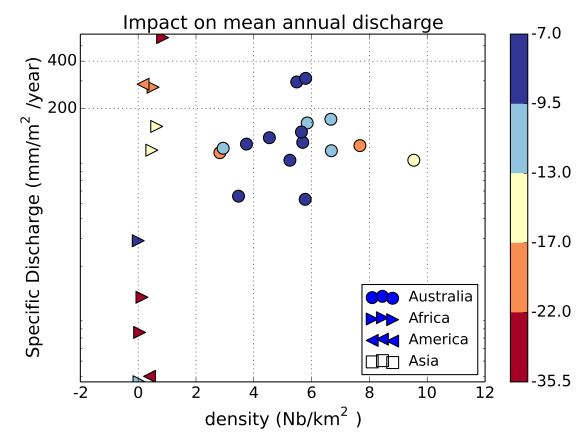

(c)

Figure 2: Cumulative impacts of the small reservoirs on the mean annual discharge (colour scale on the right), estimated from studies reported in Appendix Table A.1, as a function of possible indicators: reservoir density expressed as the number of dams per square kilometre and as storage capacity in cubic meter per square kilometre, annual precipitation expressed in $\mathrm{mm} / \mathrm{m} 2 /$ year, or specific discharge expressed in $\mathrm{mm} / \mathrm{m}^{2} /$ year. Each point represents a catchment, and the symbol corresponds to different regions: Africa, America, Asia, and Australia.

\section{How do small reservoirs impact hydrology?}

Small reservoirs have an impact on hydrology because they affect the natural water cycle that would occur without reservoirs. To understand how networks of small reservoirs impact river flow at the basin scale, it is necessary to understand the functioning of a single reservoir, how it can have an impact on the river flow and why the impact varies in time and from one reservoir to another.

\subsection{Water balance of a small reservoir}

Figure 3 presents the various terms of the water balance of the reservoir. From a general perspective, the reservoir water balance can be expressed by the following equation: 


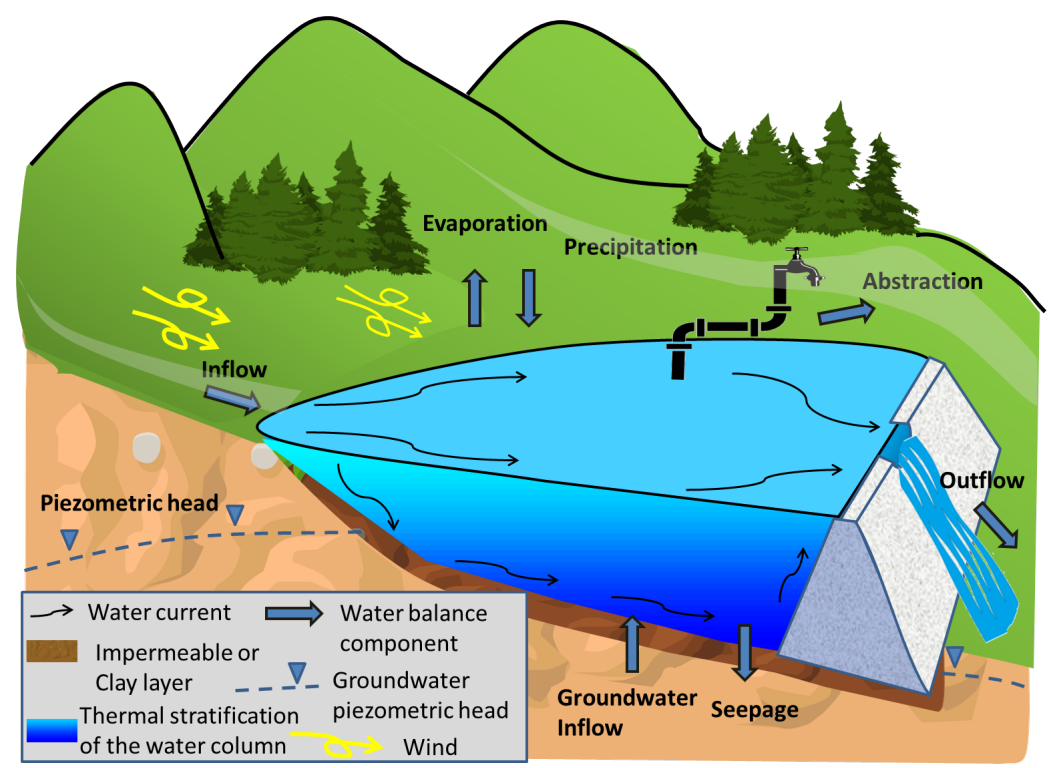

Figure 3: Water balance of a small reservoir and its main drivers. The components of the water balance are indicated by large arrows: inputs can be inflows, such as upstream runoff, lateral surface runoff, and direct precipitation; outputs can be outflows, abstraction, seepage and evaporation.

$$
\frac{d V}{d t}=Q_{\text {in }}+P+G W_{\text {in }}-Q_{\text {out }}-E-S-Q_{a b s}
$$

Here, $d V$ is the water volume variation $\left[\mathrm{m}^{3}\right]$ over the period $d t[s], Q_{i n}$ is the stream inflow to the reservoir $\left[\mathrm{m}^{3} / \mathrm{s}\right], Q_{o u t}$ is the outflow from the reservoir $\left[\mathrm{m}^{3} / \mathrm{s}\right], E$ is the evaporation rate $\left[\mathrm{m}^{3} / \mathrm{s}\right], P$ is the precipitation rate $\left[\mathrm{m}^{3} / \mathrm{s}\right], S$ is the seepage rate $\left[\mathrm{m}^{3} / \mathrm{s}\right], G W_{\text {in }}$ is the groundwater inflow $\left[\mathrm{m}^{3} / \mathrm{s}\right]$ and $Q_{a b s}$ is the water abstraction $\left[\mathrm{m}^{3} / \mathrm{s}\right]$.

Inflow can have 4 sources: i) the upstream flow, which depends on the way in which the reservoir is connected to the river (Section 3.3); ii) the surface runoff from the area directly drained by the reservoir along its bank; iii) the intercepted precipitation; and iv) a groundwater inflow, although none was reported in the literature review.

Outflux includes outflow (downstream flow) and water abstraction, as well as evaporation and seepage losses from the reservoir. Outflow is defined as the downstream flow due to reservoir release. Abstraction corresponds to the water uptake, often by pumping, for human use (irrigation, livestock watering, and so forth). Seepage flow may occur as water infiltration through the reservoir bed or through or below the dam.

All these fluxes can vary considerably from one reservoir to another. For instance, abstraction 
can be the main output, especially for farm reservoirs. However, it can also be null, such as in storm water or check dam reservoirs. Section 6.3 discusses how abstraction can be estimated at the basin scale.

Water losses are present for every type of reservoir, but with a large spread of intensity, ranging from the main outflux to negligible ones. The next section focuses on these losses and on how they can be estimated.

\subsection{Losses from small reservoirs}

\subsubsection{Seepage}

Seepage (also called percolation flux) may be particularly important to consider for small reservoirs because most of these reservoirs are built with earthen dams. The seepage rate depends on the hydraulic head gradient between the reservoir and the underlying aquifer (or unsaturated zone) or dam wall, as well as on the hydraulic conductivities of the aquifer and reservoir bed material.

Although seepage is a loss at the reservoir scale, the water is not lost and is mostly diverted. Indeed, infiltration tanks, encountered especially in Asia, are built to favour infiltration through the reservoir bed to increase the groundwater recharge. In this way, a larger part of the monsoon flow is stored in the groundwater while avoiding the evaporation loss from reservoirs during the dry season (Glendenning et al., 2012). However, when dams are intended to store water over the long term, seepage is considered as a loss. In such cases, impervious layers of clay or geomembrane (Alonso et al., 1990; Yiasoumi and Wales, 2004) are used to reduce seepage, but their efficiency decreases with age. Thus, irrespective of the intended function of the reservoir, it is rather important to estimate the seepage rate from the reservoir because it determines its efficiency for storing water (then, a low seepage rate is expected) or within the groundwater (then, a high seepage rate is expected). In the literature, estimations of the seepage rate were based on water balance approaches constrained by local observations of the precipitation, potential evaporation and reservoir's water level (Culler, 1961; Kennon, 1966; Sukhija et al., 1997; Singh et al., 2004; Bouteffeha et al., 2015), as well as on additional observations of the soil moisture and piezometric heads (Shinogi et al., 1998; Antonino et al., 2005; Massuel et al., 2014), environmental tracers (Sukhija et al., 1997), or more frequently on modelling approaches (Zammouri and Feki, 2005; Boisson et al., 2014; Jain and Roy, 2017).

Figure 4 presents some estimations of the seepage and evaporation losses from the literature 
under different hydroclimatic contexts and for reservoirs built for various purposes. Most esti-

mated seepage values are greater than $5 \mathrm{~mm} /$ day on average in the studied periods, and thus, the seepage rate appears to be higher than the evaporation rate. However, most of the values found in the literature are from percolation tanks, i.e. from dams built to promote a rapid infiltration of the runoff during the wet season to recharge the water table. For the other types of dams, the estimations can be lower: less than $1 \mathrm{~mm} /$ day for Culler (1961) in the US and up to $6.2 \mathrm{~mm} /$ day for Shinogi et al. (1998) over a 6-month period in a basin in Brazil. Fowler et al. $(2012,2015)$ consider that hillslope dams in Australia are not efficient for storing water if the seepage rate is greater than $5 \mathrm{~mm} /$ day.

When the cumulative impacts are considered, both the seepage rate and the seepage fate are important. In the case of infiltration into the dam wall, the seepage water might flow downstream in the river, and thus, the seepage flux might not be lost at the scale of the river basin. An illustration of such a process was provided by Kennon (1966), who observed that ephemeral rivers have become permanent after the implementation of dams built to prevent erosion (see Section 4.1.1), and by those studies that include groundwater recharge from dam seepage (Ramireddygari et al., 2000; Barber et al., 2009; Smout et al., 2010; Shinde et al., 2010; Perrin et al., 2012). Therefore, seepage fluxes from each reservoir should not be aggregated to estimate the loss at the basin scale and thus for the estimation of the cumulative impacts of small dams on hydrology.

\subsubsection{Evaporation}

Unlike seepage, evaporation fluxes from each reservoir should be aggregated at the basin scale. The impact of the reservoirs on the evaporation losses is then the difference between the evaporation from the land cover that was present prior to the dams being built and the evaporation from the reservoirs. Such estimations are not straightforward, particularly because the heat storage of the water body affects the surface energy flux (Assouline et al., 2008; McMahon et al., 2013). This storage partly depends on the temperature of the water columns, which is impacted by the depth of the dams (although in opposite ways depending on the references (Girard, 1966; Martínez Alvarez et al., 2007; Magliano et al., 2015) due to the associated change in the free water area); on the water circulation within the reservoir (which is also impacted by the reservoir's management); and on the interaction with the edges, which can be rather close for small reservoirs and that affects the wind velocity and the advection of air humidity (Figure 3). Several methods were used to provide estimations of the evaporation from small reser- 


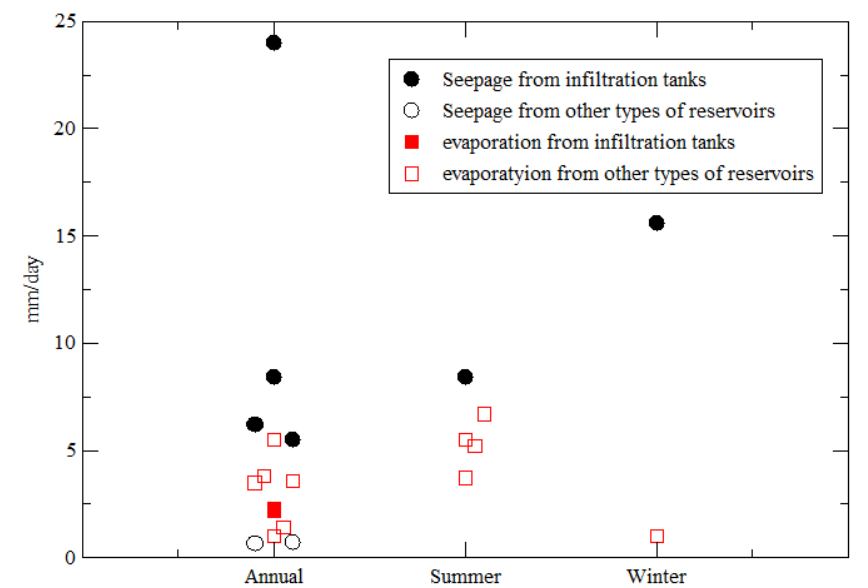

Figure 4: Estimation of the seepage loss and the evaporation flux of small reservoirs on a seasonal to annual basis. Two types of reservoirs are distinguished: infiltration reservoirs and other types of reservoirs. The values are taken from the articles cited in this section.

voirs based on observations: energy balance approaches (Anderson, 1954; Culler, 1961; Kennon, 1966; Gallego-Elvira et al., 2010), eddy-covariance measurements (Rosenberry et al., 2007; Tanny et al., 2008; Mengistu and Savage, 2010; Nordbo et al., 2011; McJannet et al., 2013), scintillometers (McJannet et al., 2013; McGloin et al., 2014), and water balance approaches (Girard, 1966; Martínez Alvarez et al., 2007). Figure 4 presents the estimations found in the literature. The mean annual estimations range from 1.4 to $5.5 \mathrm{~mm} /$ day, and the reported summer values are all above $3 \mathrm{~mm} /$ day.

Martínez Alvarez et al. (2007) proposed a relationship between the small reservoir evaporation loss and the Class A pan evaporation that varies according to the reservoir's depth and area and that varies in time (from 86 to $94 \%$ ).

Several estimations of the small reservoir evaporation loss based on meteorological data were proposed (de Bruin, 1978; Martínez Alvarez et al., 2007; McJannet et al., 2013; McMahon et al., 2013; Morton, 1983). Benzaghta and Mohamad (2009), Martínez Alvarez et al. (2008) and Craig (2008) found that the evaporation losses from reservoirs can be very important at the regional scale and have an important economic impact.

Several techniques might help reduce evaporation from reservoirs: casual chemical treatment 
to modify the albedo or form a monolayer film, completely or partially covering the reservoirs, managing the reservoir edges to reduce wind speed, and optimizing the use of the water in reservoir networks based on the temperature of the water in the reservoirs (Barnes, 2008; Lund, 2006; Assouline et al., 2011; Martínez-Alvarez and Maestre-Valero, 2015; Gallego-Elvira et al., 2011; Carvajal et al., 2014; Reca et al., 2015). However, such techniques are not yet widely used and are not considered in the existing cumulative impact studies.

\subsection{Connection to the stream}

By itself, the connection of the reservoir to the stream is key to understanding the impacts of the reservoir on the river flow. Indeed, this connection will impact both the inflow and the outflow. Small reservoirs can collect all the upstream flow (Figure 5-a for a hillslope reservoir or dam situated on the stream with no minimum flow) or only a part of the flow (reservoir with minimum flow by-pass, Figure 5-b, which allows maintaining a minimum flow, or dam situated in diversion Figure 5-c since in this case, the reservoir can not fill as long as inflow does not exceed some thresholds). In the case that all the upstream flows are collected, the downstream outflow will primarily depend on the level of the spill and on the reservoir water storage. Following "fill-and-spill" (Deitch et al., 2013), downstream discharge occurs only when the reservoir is fully filled; conversely, as long as the reservoir has not reached its capacity, downstream discharge is null. Therefore, it is possible to have periods with no downstream flow while upstream flow exists, such as for hillslope reservoirs and check dams. Such reservoirs have strong impacts on the intensity and the duration of low flows. In particular, the resumption of flow in the fall can be significantly delayed. In the case of diversion or a minimum flow bypass reservoir, a downstream flow is ensured when the upstream flow is non-zero. If the reservoir is located in diversion, then the filling period of the reservoir can be managed such that the reservoir may have no impact on the river flow during parts of the year, which may allow preserving the ecological function of the river. This management can also be adapted to the hydrological situation of each year. The reservoirs built mainly to favour groundwater recharge can have all types of connections with the river; however, it appears that most of them are built directly in the river stream, thus collecting all the upstream flows (Shinogi et al., 1998; Siderius et al., 2015). Depending on the respective inflow and abstraction dynamics, cumulative abstraction may exceed the reservoir storage capacity, as illustrated in Figure 5 for example, for which the abstractions from the reservoirs reach 105 to $120 \%$ of the maximum storage capacity. 
a) Hillslope reservoir

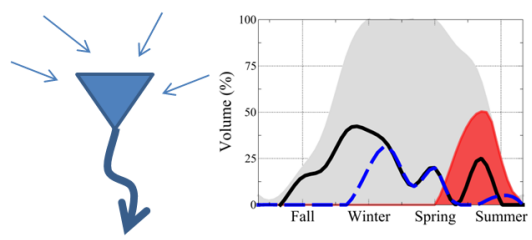

b) Reservoir with minimum flow bypass

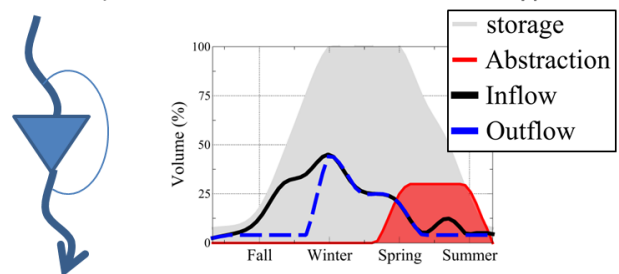

c) Reservoir in diversion

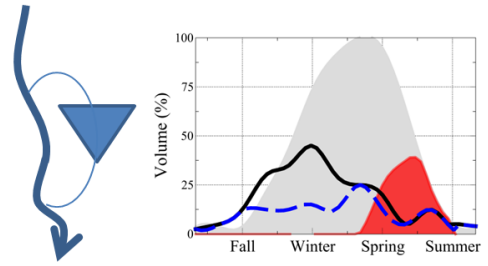

Figure 5: Illustration of 3 different connections between the river and the reservoir and its consequences in terms of river flow. Inflow, outflow and abstraction are accumulated weekly values, whereas storage is a weekly value. They are all expressed as a fraction of the maximum storage. Abstractions in the reservoirs reached 105 to $120 \%$ of the maximum storage capacity. a) Hillslope reservoir is managed as a fill and spill, with a weak and irregular inflow. b) The minimum flow bypass ensures that a minimum outflow occurs as long as inflow is present. c) The reservoir in diversion is expected to fill up as soon as the inflow reaches a given minimum flow or depending on management practices.

\section{Methods to estimate the cumulative impacts of small reservoirs on hydrology}

Quantifying the cumulative impacts of small reservoirs has been conducted using a variety of methods, all of them requiring data and observations. Two classes of methods can be distin-

based on hydrological modelling.

\subsection{Exclusively data-based methods}

4.1.1. From observation of selected reservoirs to estimation of cumulative impacts

This approach was mainly used in early works performed from the 50s to the early 70s in the US (Kennon, 1966; Culler, 1961; Frickel, 1972) and in Brazil (Dubreuil et al., 1968; Dubreuil and Girard, 1973; Molle, 1991). In light of these pioneering works, it can be observed that the 
cumulative impacts on hydrology have been a scientific and water management issue for a long time.

Despite some differences in the methodology among these studies, they all aimed at quantifying single reservoir hydrologic functioning from the monitoring of a sample of reservoirs. Losses were estimated using a mass balance of the sampled representative reservoirs based at least on the monitoring of the water level, inflows and outflows of the reservoirs. These early studies initially made the assumption that cumulative reservoir impacts were the sum of the impact of each reservoir following an aggregation process. However, the main outcome of these studies was to show that this assumption was not valid. Indeed, Culler (1961) and Kennon (1966) found that the seepage was a significant loss for the sampled reservoirs but contributed to downstream flow. Therefore, interactions between reservoirs and hydrologic compartments, especially the stream, were identified very early as processes to be taken into consideration to reliably estimate the cumulative impacts.

\subsubsection{Statistical analyses of the observed discharge}

The idea is to connect the detected changes in the statistical properties of river discharge time series with the evolution of the reservoir network within the basin. In doing so, the details of each reservoir functioning are not taken into consideration. To our knowledge, this type of study based solely on observations was only performed by Galea et al. (2005). A study based on a 30-year river discharge time series of two French catchments showed no stationarity break in summer, while a break was shown in winter, i.e., during the filling period (Galea et al., 2005).

One difficulty of such statistical analyses is discriminating the specific impact of small reservoirs from those of land use and land cover (LULC) evolution or of climate change (CC). Reservoir development occurred over decades, a sufficiently long period to be sensitive to LULC modifications (such as agricultural intensification or crop modification) and CC. To overcome this issue, Schreider et al. (2002) compared the observed river flows with simulated ones obtained using the observed atmospheric forcing, but without any explicit representation of the small dams in the models. The IHACRES rainfall-runoff model, a dynamic, lumped parameter model, was used to simulate stream flow with parameters calibrated considering periods before the development of reservoirs. They found significant decreasing trends in the observed discharge of basins that had a development of farm dam capacity, and they were able to attribute these trends to non-climatic stressors since such trends were not simulated with a reservoir-free basin. 


\subsubsection{Paired-catchment experiment}

A paired-catchment experiment is an approach already used in hydrology for quantifying the impact of LULC changes from a comparative analysis of stream flows monitored in two contrasted catchments (see, for instance, Brown et al. (2005) for a review in forest hydrology). Thompson (2012) is, to our knowledge, the only study using this approach to compare stream flows from two adjacent and similar catchments, one without a reservoir and the second with three small reservoirs. From an 18-month monitoring, annual stream flow was estimated to be lower by $40 \%$ in the catchment with 3 reservoirs than in the "no-reservoir" catchment (Thompson, 2012). Although the experiment found differences in the specific discharge, the full comparison of the water balance remained difficult. The main shortcoming of Thompson's approach is that catchment properties (soils, lithology, land cover, topography, and so forth) were spatially heterogeneous over a short distance, making deciphering the stream flow differences difficult. Furthermore, indirect reservoir impacts on land use, such as the cattle grazing around the reservoir in Thompson's case study, can also modify stream flow. The study would have benefited from following the classic approach used in paired-catchment experiments, implying a calibration period where both catchments are monitored, followed by a period when one of the catchments is subjected to land use change (reservoir building) and the other remains as a control. However, building a reservoir network over a large area is generally difficult for practical and financial reasons. Consequently, such an approach has never been utilized to our knowledge.

\subsection{Modelling approaches}

Modelling is the most widely used approach for studying and quantifying the cumulative impacts of small reservoirs. Although various modelling approaches have been developed, all are based on the coupling of the small reservoir water balance model with a quantitative method to estimate stream inflow into the small reservoirs. Three of the main model components are detailed below: i) the small reservoir water balance model, ii) the quantitative method used to quantify inflow to reservoirs, and iii) the spatial representation of the reservoir network. The inflow quantification method and the spatial representation of the reservoir have to be consistent and are thus intrinsically dependent. A spatially distributed representation of reservoirs requires being able to estimate the spatial distribution of stream flow to estimate the upstream inflow to each reservoir. Conversely, an aggregated estimation of stream flow over a sub-basin or over the full catchment leads to the reservoir network representation being aggregated on the same 
domain.

Most of the reviewed studies focused on assessing the impacts of reservoirs used for irrigation or livestock watering on stream flow. In such cases, the impacts are quantified by comparing the catchment stream flow simulation with and without reservoirs, except for the TEDI model, as we will see in Section 4.2.2. The exceptions to modelling approaches dedicated to stream flow impacts are those aiming at assessing the impacts on groundwater. These approaches mostly focus on infiltration tanks, for which part of the stored volume recharges the aquifer. In such cases, only the impacts on the aquifer due to the loss from the reservoirs are represented, either without simulation of the groundwater (Martín-Rosales et al., 2007; Hughes and Mantel, 2010), with a simplified representation of the aquifer (Smout et al., 2010; Shinde et al., 2010; Perrin et al., 2012), or even more seldom, with a 2-D hydrogeological model (Ramireddygari et al., 2000; Barber et al., 2009).

\subsubsection{Reservoir water balance model}

Reservoir water balance models rely on equation (1). Most small reservoir water balance models take into account the evaporation and abstraction, for which temporal estimation is rarely well known and is often an important point (see Section 5.3) (Table 1). When seepage is taken into account, it is considered only as infiltration to groundwater. Ignoring seepage is justified by the small expected rates (Hughes and Mantel, 2010) or by the lack of information on the process (rate, timing, and driving factor Güntner et al. (2004)) and by the fact that seepage flux can contribute to downstream flow. To simulate the reservoir water mass balance, downstream discharge is simulated considering that reservoirs operate with the technique of "fill-and-spill" (Section 3.3, unless a conservation flow is taken into account (Table 1). Reservoir inflow is simulated by different approaches, as presented in the next section.

\subsubsection{Reservoir inflow quantification}

In most modelling approaches, upstream inflow is provided by a catchment hydrological model simulating the water balance (WB), or the energy and water balance (EWB), in the upstream catchment and the routing of the flow downstream (Table 1). Existing catchment hydrological models are used in the modellings, reflecting the diversity of current hydrological models. Such models need atmospheric forcing and some information on the land cover, soil and topography, unless the model parameters are calibrated without any data on the physiographic characteristics. Two models, TEDI and Deitch (Table 1), developed an alternative and pragmatic 
method based on using observed discharge time series as input to the model. In doing so, the TEDI and Deitch models do not belong to any current modelling approaches. Using observed discharge at available river gauges implies being able to successively i) disentangle the natural flow from the anthropogenic flow and ii) distribute the observed discharge along the reservoir networks. To achieve the first step, Deitch et al. (2013) used historical gauged discharge measured prior to the reservoir pre-development period. The discharge was then spatially distributed according to the drainage area of each reservoir and the spatial distribution of the average annual rainfall. The propagation of stream water was then operated from the most upstream reach to the catchment outlet by considering the water volume intercepted in each reservoir. The cumulative impact of reservoirs is then classically the difference between simulated discharge and the gauged discharge. In TEDI, Nathan et al. (2005) used the observed discharge of the period of interest. The inflow in each reservoir is calculated from the observed catchment discharge assuming a proportionality with the reservoir catchment area. The outflow from every reservoir is transfered directly to the outlet. It is then considered that the obtained cumulative impact corresponds to twice the simulated impact of the reservoir network because the gauge discharge already includes the impacts of existing reservoirs.

\subsubsection{Reservoir spatial representation}

How the reservoir network is represented from a spatial perspective varies from one model to another. The spatial representation of the reservoir network can be classified into the following three types (see Figure 6, Table 1).

- In the spatially aggregate approach, all the reservoirs in a catchment (in Table 1, A for aggregation on sub-catchments and $\mathrm{A}^{*}$ for aggregation on a grid cell) are represented in the form of a single equivalent, or composite, reservoir.

- The statistical representation constitutes a refinement of the aggregate representation (Figure 6-B). The reservoir network is represented in the model in an aggregated way by grouping reservoirs into a finite number of classes. Some hydrological connections between several of these classes may be represented ( $\mathrm{S}$ in Table 1).

- The spatially explicit representation consists of representing every reservoir (Figure 6-C). 


\begin{tabular}{|c|c|c|c|c|c|c|c|c|c|}
\hline \multirow[b]{2}{*}{ Model } & \multirow[b]{2}{*}{ 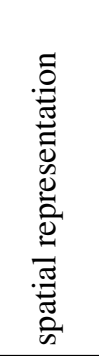 } & \multirow[b]{2}{*}{ 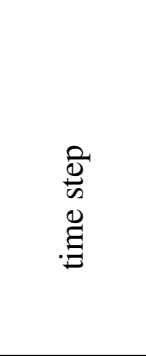 } & \multicolumn{7}{|c|}{ Processes included } \\
\hline & & & $\begin{array}{l}\stackrel{3}{0} \\
\stackrel{\Xi}{!}\end{array}$ & $\begin{array}{l}3 \\
0 \\
\stackrel{\Xi}{\Xi} \\
0 \\
0\end{array}$ & 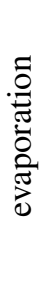 & 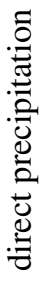 & 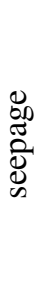 & $\stackrel{\stackrel{\dot{D}}{\leftrightarrows}}{\stackrel{\Xi}{\Xi}}$ & 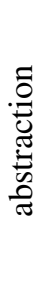 \\
\hline $\mathrm{CRU}^{i}$ & A & day & WB & CF spill & $\mathrm{x}$ & $\mathrm{x}$ & $\mathrm{x}$ & & $\mathrm{X}$ \\
\hline GR4 $J^{k}$ & A & day & WB & & & & & & \\
\hline HYDROMED $^{l}$ & A & day & WB & spill & $\mathrm{x}$ & $\mathrm{x}$ & & & $\mathrm{x}$ \\
\hline POTYLDR $^{j}$ & A & day & WB & CF spill & $\mathrm{x}$ & $?$ & $\mathrm{x}$ & $?$ & $\mathrm{x}$ \\
\hline ISBA-Rapid $^{h}$ & $A^{*}$ & hour & EWB & spill & $\mathrm{x}$ & & & & $\mathrm{x}$ \\
\hline SWAT & $\mathrm{A}^{g}, S^{n}$ & day & WB & spill & $\mathrm{x}$ & $\mathrm{x}$ & & $\mathrm{x}$ & $\mathrm{x}$ \\
\hline $\mathrm{TEDI}^{a}$ & S & month/day & OBS & spill & $\mathrm{x}$ & $\mathrm{x}$ & & & $\mathrm{x}$ \\
\hline WASA $^{d}$ & S & day & WB & spill & $\mathrm{x}$ & & $\mathrm{x}$ & & $\mathrm{x}$ \\
\hline WaterCAST $^{c}$ & S & day & WB & spill & $\mathrm{x}$ & $\mathrm{x}$ & & & $\mathrm{x}$ \\
\hline CASCADE $^{m}$ & $\mathrm{D}$ & day & WB & spill & $\mathrm{x}$ & & $\mathrm{x}$ & & $\mathrm{x}$ \\
\hline CHEAT $^{b}$ & $\mathrm{D}$ & month & OBS & spill & $\mathrm{x}$ & $\mathrm{x}$ & & & $\mathrm{x}$ \\
\hline Deitch et al..$^{e}$ & $\mathrm{D}$ & day & OBS & spill & & & & & \\
\hline PITMAN $^{f}$ & A & month & WB & spill & $\mathrm{x}$ & & & & $\mathrm{x}$ \\
\hline
\end{tabular}

Table 1: Main processes in reservoir water balance model, as well as temporal and spatial representations of reservoirs in numerical models. Spatial representation can be the following (see Figure 6): A: aggregate representation by catchment (or A* by grid in grid-based models), $\mathrm{S}$ : statistical representation, or D: distributed representation. Inflow to the reservoirs can be derived from OBS: observations, WB: water balance, or EWB: energy and water balance. Outflow is computed either based on spill (above a water level or volume in the reservoir) and/or taking into account a conservation flow (CF). ${ }^{a}$ : Nathan et al. (2005), ${ }^{b}$ : Nathan et al. (2005), ${ }^{c}$ : Cetin et al. (2009), ${ }^{d}$ : Güntner et al. (2004), ${ }^{e}$ : Deitch et al. (2013), ${ }^{f}$ : Hughes and Mantel (2010), ${ }^{g}$ : Perrin et al. (2012), ${ }^{h}$ : (Habets et al., 2014), ${ }^{i}$ : Tarboton and Schulze (1991), ${ }^{j}$ : Ramireddygari et al. (2000), ${ }^{k}$ : Payan et al. (2008), ${ }^{l}$ : Ragab et al. (2001), ${ }^{m}$ : Shinogi et al. (1998); Jayatilaka et al. (2003), and ${ }^{n}$ : Zhang et al. (2012) 


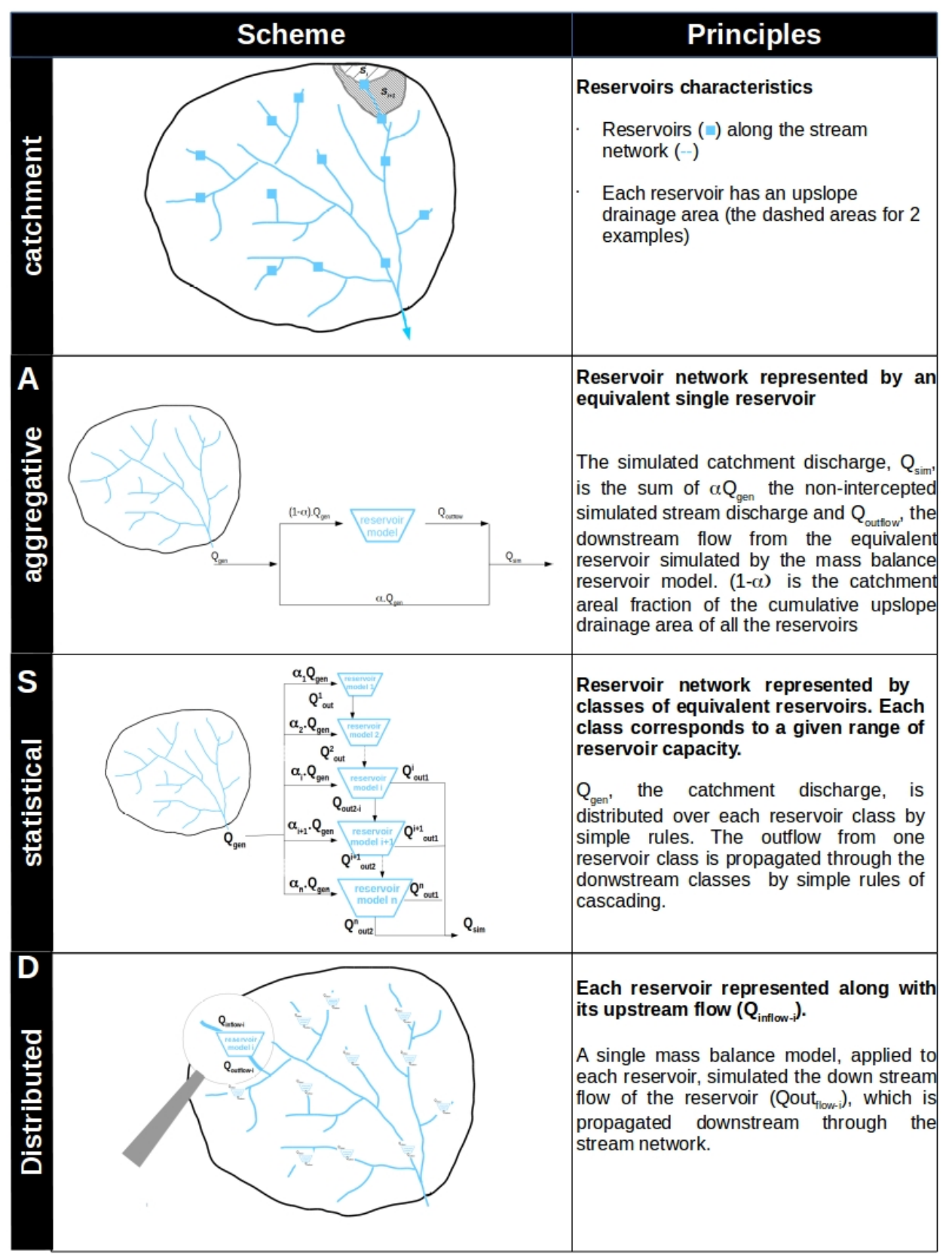

Figure 6: Spatial representation of reservoir network in models used to quantify cumulative reservoir hydrologic impacts. 


\section{Aggregate representation}

In the aggregate representation (Figure 6-A), the characteristics of the equivalent reservoir (capacity and surface area) are obtained by aggregating single reservoir characteristics. The main interest of the aggregate representation is to require only global information about the reservoirs and their characteristics. In fact, the spatial density of reservoirs within a catchment can be large, greater than 10 reservoirs $/ \mathrm{km}^{2}$ in some cases (Nathan et al., 2005), and an exhaustive inventory of all reservoirs along with their characteristics is out of reach. Rather, a global estimation of reservoirs and their characteristics may be approximated from simple rules of spatial extrapolation (cf. Habets et al. (2014)). For instance, to estimate the inflow into the equivalent reservoir, it is necessary to determine the contributive catchment. It can be a fraction of the catchment area (Tarboton and Schulze, 1991; Hughes and Mantel, 2010) that can be estimated from the sum of the drainage area of all reservoirs or depending on the cumulative reservoir area (Habets et al., 2014)

The aggregate representation leads to obtaining a simulation of the hydrological cumulative impacts of reservoirs at the catchment, grid-cell or sub-catchment outlet but intrinsically does not allow simulating the cumulative impacts along the river network from the head to the outlet, unless the sub-catchments are small, which is often not the case because the size of the sub-catchment is often determined by the availability of river gauges. Furthermore, this representation may not reflect the different responses of the various reservoirs in terms of key processes (evaporation, infiltration, operations, and so forth (Zhang et al., 2012)).

\section{Statistical representation}

The statistical representation is a trade-off between the other two representations. It considers that information about the location and characteristics of reservoirs, particularly of smalland medium-sized reservoirs, cannot be exhaustively available. It also relies on the assumption that reservoir connectivity may play a role in the cumulative impacts. The reservoir network is represented by classes of reservoirs determined following reservoir water capacity (Güntner et al., 2004; Nathan et al., 2005; Lowe et al., 2005)) and also reservoir drainage area (Zhang et al., 2012). Each class is represented as a single equivalent reservoir. Güntner et al. (2004) and Zhang et al. (2012) used a coupled sequential and parallel scheme to represent the upstream-downstream connectivity of different water reservoir classes in the catchment.

As a main advantage, the statistical representation has to consider the diversity of key reser- 
voir processes, which can be variable from one reservoir to another but quite homogeneous in reservoirs of similar sizes. In this way, it overcomes one of the main shortcomings of the aggregate representation. Evaporation, for example, depends on the water column height and circulation within the reservoir, which is expected to depend on reservoir size (cf. Section 3.2). Connectivity to the network -reservoirs and rivers- and operation rules may also be different depending on the reservoir function, which also depends on the reservoir size. Another advantage of the statistical representation is being computationally faster than the fully distributed one because fewer reservoir mass balances have to be computed and water transfers between reservoirs are simplified. The main shortcoming is that it does not obtain distributed simulations of the hydrological impacts of reservoirs; particularly, the cumulative impacts along the full river network cannot be simulated.

\section{Distributed representation}

A distributed representation of the reservoir is the only way to explicitly represent the interactions between reservoirs by considering the outflow from one reservoir as a contribution to the inflow of the downstream one and the interactions between reservoirs and hydrological compartments (river, soil, and aquifer) by estimating the impacts of each reservoir on its connected river reach or/and aquifer. Indeed, two dams with similar characteristics may have different impacts according to their location along the stream network, mostly because the inflow is not the same. The interest in a spatially explicit representation is in quantifying and understanding the local hydrologic impact at a river reach scale and the cumulative impacts along the river network (Deitch et al., 2013). Quantifying local hydrologic impacts may be particularly relevant to water quality, ecological disturbance or morphogenesis evolution. In a spatially explicit representation, water inflow into every single reservoir as stream discharge and lateral surface runoff has to be known or estimated. To our knowledge, only Shinogi et al. (1998) and Smout et al. (2010) have performed catchment hydrologic modelling to obtain these estimations, with an application to relatively simple case studies characterized by few reservoirs. Other reported case studies using spatially explicit representations used observed-stream-discharge-based models (Nathan et al., 2005; Cetin et al., 2009; Deitch et al., 2013).

A spatially explicit representation relies on the availability of exhaustive information about reservoir location, characteristics, water uses and topology, which are rarely available over large areas. This point constitutes a main shortcoming of the approach, as addressed in Section 4.1.1. 
Furthermore, it can be expected that uncertainties in the local information, added to the uncertainty in estimated spatial discharge and individual reservoir water balances, can skew the local simulated impacts, and by propagation, the cumulative impacts. This could alleviate the theoretical interest in the spatially explicit representation. Acknowledging the lack of information and the difficulty to obtain it exhaustively, statistical representations and aggregate representations are considered as pragmatical solutions and used in most modelling studies.

\section{How to obtain access to the information needed on small reservoirs?}

\subsection{What type of data?}

Stream discharge time series, at one or several points in the catchment, are required data in statistical analyses (Section 4.1.2) and in the TEDI and Deitch models (Nathan et al., 2005; Deitch et al., 2013, section 4.2.1), and such data are also used by the other types of models to calibrate or assess the modelling. Such data are expected to be found in existing databases. Statistical analyses require rather long observation periods for both the discharge and the temporal evolution of the reservoir network to cover contrasted periods. The modelling approaches generally need to collect more data, even if focusing on a shorter time period. These data include atmospheric and physiographic data, as well as the characteristics of each reservoir (or of the aggregated ones), the connection between the reservoirs, and the management of the reservoirs, particularly in terms of abstraction. Table 2 presents some of the most commonly required data on the reservoirs used for such studies.

\subsection{Physical and topographical characteristics of small reservoirs}

Data on small reservoir characteristics may be collected and stored in databases by stakeholders or state or regional agencies. Although they are often a first base to initiate a study and may prove very useful, such databases are generally incomplete, even for the census of the reservoirs, either because the survey did not include all the existing reservoirs or because the database is not up to date. Moreover, all the needed data are not available. Therefore, to fill the gaps, several methods can be used: i) additional field surveys, ii) remote sensing data (either satellite or aerial images) and related image analysis techniques and iii) empirical relationships to recover one variable according to other properties. In most studies, several methods are combined.

Here, only some indications on the available methods are presented because it is beyond the scope of the present review to fully describe such techniques. Some details can be found 


\begin{tabular}{|c|c|c|c|}
\hline Variables & Description & $\begin{array}{l}\text { Spatial repre- } \\
\text { sentation }\end{array}$ & Access \\
\hline Number & $\begin{array}{l}\text { number of reservoirs in } \\
\text { catchment }\end{array}$ & $\mathrm{D} / \mathrm{C} / \mathrm{S} / \mathrm{A}$ & DB/RS/Map \\
\hline Location & geographical coordinates & $\mathrm{D} / \mathrm{C}$ & DB/RS/Map \\
\hline $\begin{array}{l}\text { River } \\
\text { flows }\end{array}$ & $\begin{array}{l}\text { observed discharge at some } \\
\text { places of the area under } \\
\text { study }\left(\mathrm{m}^{3} / \mathrm{s}\right)\end{array}$ & $\mathrm{D} / \mathrm{C} / \mathrm{S} / \mathrm{A}$ & $\mathrm{DB}$ \\
\hline $\begin{array}{l}\text { Maximum } \\
\text { area }\end{array}$ & $\begin{array}{l}\text { area of the free surface wa- } \\
\text { ter }\left(m^{2}\right)\end{array}$ & $\mathrm{D} / \mathrm{C} / \mathrm{S} / \mathrm{A}$ & DB/RS/Map \\
\hline $\begin{array}{l}\text { Drainage } \\
\text { area }\end{array}$ & $\begin{array}{l}\text { upstream basin whose runoff } \\
\text { may feed the reservoir(s) }\end{array}$ & $\mathrm{D} / \mathrm{C} / \mathrm{S} / \mathrm{A}$ & $\mathrm{DB} / \mathrm{ER}$ \\
\hline $\begin{array}{l}\text { Storage } \\
\text { capacity }\end{array}$ & $\begin{array}{l}\text { maximum capacity volume } \\
\text { of the reservoir }(\mathrm{s})\left(\mathrm{m}^{3}\right)\end{array}$ & $\mathrm{D} / \mathrm{C} / \mathrm{S} / \mathrm{A}$ & $\mathrm{DB} / \mathrm{RS} / \mathrm{ER}$ \\
\hline Abstraction & $\begin{array}{l}\text { volume and timing of } \\
\text { water uptake in the } \\
\text { reservoir }(s)\left(\mathrm{m}^{3} / \text { period }\right)\end{array}$ & $\mathrm{D} / \mathrm{C} / \mathrm{S}$ & $\mathrm{DB} / \mathrm{ER}$ \\
\hline $\begin{array}{l}\text { River con- } \\
\text { nection }\end{array}$ & $\begin{array}{l}\text { hillslope, across the river } \\
\text { course, in diversion }\end{array}$ & $\mathrm{D} / \mathrm{S}$ & DB/RS/Map \\
\hline Bathymetry & $\begin{array}{l}\text { relations between height- } \\
\text { water volume-water free wa- } \\
\text { ter surface area }(\mathrm{m})\end{array}$ & $\mathrm{D} / \mathrm{S}$ & $\mathrm{DB} / \mathrm{RS} / \mathrm{ER}$ \\
\hline Age & $\begin{array}{l}\text { time since building the } \\
\text { reservoir (year) }\end{array}$ & $\mathrm{D} / \mathrm{S}$ & DB/RS/Map \\
\hline
\end{tabular}

Table 2: Key variables needed to conduct a cumulative impact study of small reservoirs from the most common (top) to the less used (bottom). Spatialization can be either D: distributed, S: statistical, C: catchment or A: aggregated (see Figure 6). Access to the variables can be from DB: databases, RS: remote sensing (satellite data, aerial images, lidar and so forth), Map: mapping, or ER: empirical relationships (see subsection below). Variables in brown are associated with the management of the reservoir discussed in Section 5.2, whereas the other ones are discussed in Section 5.3. 
in Nathan et al. (2005); Lowe et al. (2005); Hughes and Mantel (2010); Malveira et al. (2012); Nathan and Lowe (2012); Bartout et al. (2015); Fowler et al. (2015).

Field surveys are not often described in the literature because they are quite basic. However, field surveys represent a guaranteed method to locate all the reservoirs on a catchment and to ensure their type of connection to the river. However, this method is time consuming and cannot be used on large areas. The detection of reservoirs is efficient with remote sensing methods based on aerial or satellite images, which allows retrieving both the number and areas of the reservoirs (Chao et al., 2008; Messager et al., 2016). However, very small reservoirs (approximately $100 \mathrm{~m}^{2}$ ) are still difficult to detect, even with high-resolution aerial images (Carvajal et al., 2014).

Storage volume and bathymetry are more difficult to assess by remote sensing (Gal et al., 2016), whereas uncertainty in the storage volume can lead to important error in impact studies (Hughes and Mantel, 2010; Fowler et al., 2015). Thus, some empirical relationships are most often used. Based on a geometrical analysis of a variety of reservoir shapes, Molle (1991) showed that the relations between the reservoir surface and volume correspond to power laws. The parameters of the laws vary in space, depending on the geomorphological context, but remain generally constant within a given region (Thompson, 2012). Consequently, a common approach is to fit the law parameters from a set of reference reservoirs. The law can then be applied to all reservoirs in the catchment (Malveira et al., 2012; Hughes and Mantel, 2010).

The drainage area of the reservoirs can be derived from digital terrain models. However, this requires having a precise position of the reservoirs to be able to connect them with the correct river reaches to avoid error in the estimation of the upstream drainage area (Hughes and Mantel, 2010). Moreover, the determination of the type of connection between the reservoir and the river is a key point for assessing how the reservoir is filled. For modelling approaches that are not fully distributed, it is possible to use some relationship between the free surface water area (or volume) and the drainage area of the reservoir. Linear (Habets et al., 2014; Nathan et al., 2005) or non-linear (Fowler et al., 2015) relationships have been used. However, these relationships are again often specific to the studied catchment and cannot be generalised to very different contexts.

\subsection{Water reservoir management characteristics}

Water reservoir management operations refer to how the volume is stored in the reservoir and released from the reservoir either downstream, outflow, or withdrawn for some usage (most often, agricultural use). The type of reservoir-stream connection is an important driver for such 
management, as shown in Section 3.3. Information on the connection can be included in some databases managed by stakeholders or regional agencies, particularly where legal regulations exist, for instance, to maintain a conservation flow. However, as stated previously, such databases are often incomplete. Hughes and Mantel (2010) show that it is difficult to obtain this information from remote sensing. Covering all the small reservoirs with a field survey is also difficult; such information is thus likely to be incomplete. This is perhaps the reason why most existing studies do not consider the ability to disconnect the small reservoirs from the stream network or to maintain some minimum flow by some type of diversion canal or low-flow bypass. Some exceptions are the works of Fowler et al. (2009) and Thompson (2012) that considered low-flow bypasses and of Habets et al. (2014) that considered the possibility to disconnect the reservoirs during part of the year (as if they were in diversion) to manage a filling period as required by the regional regulation. However, a limitation is that in these cases, the management operations were supposed to be homogeneous within the basin.

Water abstraction is the most sensitive information needed to infer the cumulative impacts of small reservoirs on hydrology (Hughes and Mantel, 2010; Fowler et al., 2015). However, the abstraction is rarely known, and at best, only an annual estimation of the abstracted water volume is known. To retrieve the temporal evolution of the water abstraction, which of course varies from year to year, several methods are used in the literature, either based on the estimation of the water demand or on the water offer (i.e. the available water volume stored in the reservoirs).

Water demand approaches attempt to quantify the needs associated with irrigating crops and watering livestock. Consumption for watering livestock is considered to be constant throughout the year (Fowe et al., 2015), whereas irrigation is estimated according to the sub-seasonal climate conditions. The water demand of the crop is often calculated on the basis of the crop coefficient Kc, which varies over time, and potential evapotranspiration (PET) (Fernández et al., 2007; Wisser et al., 2010; Biemans et al., 2011; Fowe et al., 2015).

Water offer approaches consider that the abstraction accounts for a given fraction of the total reservoir capacity. This approach is mainly used in Australia (Nathan et al., 2005; Cetin et al., 2009; Fowler et al., 2015). The fraction of the total storage can be obtained through surveys of reservoir owners or occasionally by remote detection (Fowler et al., 2015) and is highly variable depending on usage (irrigation vs. watering livestock) and region. Nathan and Lowe (2012) refers to fractions ranging from $10 \%$ to $400 \%$, which implies that the reservoir can be filled 
several times within a year. Although rather simple, this method allows considering a seasonal distribution of the abstraction according to known uses (Cetin et al., 2009). This method can also be used when no information on the abstractions is available simply by assuming that the abstraction volume is a given fraction of the storage capacity (Habets et al., 2014; Deitch et al., 2013).

\section{Discussion}

\subsection{The uncertainty issue}

Regardless of the approach (exclusively data-based method or modelling approaches), stream flow is a crucial variable in any reservoir impact estimation and may be a source of uncertainty in cumulative impact estimation. The uncertainty arises from uncertain measurements of stream flow, including the need to transpose data from neighbouring catchments, as well as from time series that are too short. It can lead to incorrect conclusions in trend analysis within statistical analyses of time series (Section 4.1.2) and in comparisons of paired-catchment hydrology (Section 4.1.3).

In modelling approaches, when catchment models are used to simulate inflow to reservoirs and transfer of reservoir outflow to the outlet, uncertainties in cumulative impact simulations derive from uncertainties classically associated with catchment hydrologic models, namely, the model itself (structure and parameters) and the data used to calibrate and validate the model. An extensive presentation and discussion of these sources of uncertainty are beyond the scope of the present review and can be found elsewhere (see, for instance, Hingray et al. (2009)). When observed discharge is used rather than hydrologic catchment models, as in Deitch's model, in TEDI or in CHEAT, the simplifications performed to spatialize observed discharge as reservoir inflow may result in strong errors in reservoir dynamics, in outflow simulation and thus in cumulative impact estimation. The assumption used to aggregate reservoir outflow may also be another source of uncertainty. To our knowledge, no sensitivity and uncertainty analyses of the simplifications and assumptions have been performed.

How the reservoirs are accounted for in the models, together with how the hydrological processes are estimated, are key components of the models. Incorrect representations may lead to significant uncertainty in the estimation of cumulative impacts. Indeed, processes and factors that affect reservoir water balance (Section 3.1) and thus cumulative impacts (Section 4.2) are 
numerous. In the approaches for quantifying cumulative impacts, choices are made irrespective of the key processes and their representation; seepage, for instance, is often neglected (Table 1). The reservoir network representations (Table 1) in models also vary from one approach to another. The physical, topographic and management characteristics of reservoirs (Table 2) may also have uncertainties due to a lack of information or measurement and survey errors. The uncertainty in the estimation of cumulative impacts is thus a key issue.

A few modelling studies have addressed this issue by conducting sensitivity analyses (Habets et al., 2014; Hughes and Mantel, 2010; Malveira et al., 2012; Nathan et al., 2005). Although incomplete, three preliminary results can be emphasized. a) The effect of the uncertainty on the estimated upstream drainage area of reservoirs on inflow is controversial. On the one hand, it was shown to be a key morphological characteristic. This would have to be expected as the larger the upstream drainage area is, the larger the flow intercepted by reservoirs (Habets et al., 2014; Hughes and Mantel, 2010). On the other hand, the stream flow was shown to not be very sensitive to the reservoir drainage area (Nathan et al., 2005). The hydrologic characteristics (annual flow, monthly flow, and flow duration curves) taken into consideration to evaluate the cumulative impacts may explain the differences between these findings. b) Water management of reservoirs appears to play a dominant role in stream flow reduction. This was clearly shown by Hughes and Mantel, quantifying the key role of water demand uncertainty confirmed by Güntner et al. (2004), stating that "local experience suggests that uncertainty in human withdrawal add the largest uncertainty". c) Nathan et al. (2005) found that for the studied Australian catchments, the spatial representation of reservoirs, especially the topology and the cascading between reservoirs, does not exert a great role on stream flow reduction within the range of reservoir distribution.

From these preliminary conclusions, we highlight in the two following sections the need and the ways to improve knowledge of reservoir characteristics and estimate water abstraction from reservoirs. Uncertainty derived from process representations also deserves a thorough analysis, particularly how reservoir evaporation is quantified and the consequence of neglecting seepage in most of the approaches. It is expected that the sensitivity and uncertainty propagation may be different as functions of the hydrologic characteristics used to assess the cumulative impacts.

\subsection{Improving knowledge of small reservoir characteristics}

Estimating the cumulative impacts of small reservoir networks requires obtaining the key physical and geometrical characteristics of networks and reservoirs (Table 2). Unlike large reser- 
voirs, the knowledge of the characteristics constitutes a real and specific challenge in consideration of the large number of small reservoirs within a catchment, up to nearly $10 / \mathrm{km}^{2}$ in some regions (Figure 2). This review shows that a variety of methods, ranging from field surveys to remote sensing, are available. However, uncertainty in the estimation of characteristics can be large and constitutes a difficulty specific to small reservoirs. One way to address this challenge is to choose methods for impact estimation that are minimally sensitive to the lack of information or uncertainty in small reservoir properties. This choice is made, for instance, in the global and statistical representations of reservoir networks used in some modelling approaches. Global indicators, as we investigated in this review, are also a way to overcome a lack of or uncertainty in information about the key characteristics of small reservoirs. However, the development of remote sensing methods and image analysis techniques should help in the future to map and quantify the properties over vast areas while reducing the uncertainties (Zhang et al., 2012). Following this approach, remote sensing may also be a way to derive height-surface area-volume relations (Mialhe et al., 2008). To date, such relationships established in a given region were used for all the reservoirs, while relations may vary from one reservoir to another. The synthesis by Carluer et al. (2016) found that operational studies collect a wealth of data on small dam network properties, data that were rarely used beyond the studies. Therefore, along with improvements in survey and remote sensing methods, one track to improve our capability of estimating small reservoir cumulative impacts also relies on storing and sharing information collected through operational surveys and scientific studies.

\subsection{Improving abstraction estimations}

When small reservoirs are intended to provide water for agricultural uses (irrigating crops and watering livestock), abstraction is a key parameter in hydrologic reservoir dynamics and in cumulative impacts (Hughes and Mantel, 2010; Nathan and Lowe, 2012). However, the present review shows that current estimations rely on very pragmatic choices and simple methods because existing, readily available information about abstraction is very difficult to obtain in every country. Water abstraction may vary broadly from one reservoir to another. Abstraction rate and timing from a given reservoir result from a complex process including biophysical considerations: crop or livestock demands, availability of reservoir water and also of other water resources (river and groundwater). Social and economic considerations are also at stake: water abstraction resulting from an agronomic strategy developed by farmers, involving crop yield and profit tar- 
gets, also related to water resource sharing between water users. Abstractions at least depend on laws or regulations fixing water use restrictions and downstream water release rates and timings from reservoirs for other water functions.

Two ways may enhance abstraction estimations. In many countries, farmers have to declare to water management agencies or state services the abstraction volumes and occasionally the timing from their own reservoirs. Storing this information through database systems and making it available would allow obtaining a precise estimation of where and when water is withdrawn from reservoirs. Empirical relations relating the characteristics of reservoirs with crop or animal needs could be one way to estimate and spatialize the water abstraction from small reservoirs more accurately than the current simple and pragmatic methods. Another way would be to take advantage of the agronomic state of the art in terms of crop management strategies. Decision rule models are available to simulate and predict tillage, sowing, fertilization, hoeing, irrigation, crop protection, and harvesting periods. Such models could be coupled to hydrologic models, allowing estimating the impacts of agricultural land use strategy in a reservoir-equipped catchment on stream flow and other water compartments. As an example, the MAELIA platform proposes a framework to couple such crop models and decisional models with the SWAT hydrologic model (Thérond et al., 2014).

\subsection{Impact indicators}

Simple indicators of cumulative impacts are needed by stakeholders and water management actors. The challenge is the design of the reservoir system and particularly the identification of sensitive areas where no other reservoir should be built, and even where some reservoirs should be removed, while other areas could benefit from the construction of new reservoirs to increase the available water resource. From a scientific perspective, this operational need consists of first analysing whether cumulative impacts can be derived from properties of reservoir networks or others. Our analysis shows that there is no relationship between the hydrological impact rates and some simple network density indicator (Figure 2). The analysis was performed based on data collected from worldwide studies involving a large range of hydrological, climatic, geological, pedological, and land use contexts. Catchment hydrological functioning, particularly runoff temporal and spatial variability, must be a key factor in the impact process, although indicators only based on reservoir properties do not account for. This point is clearly supported by the variability of impacts for a given catchment depending on wet and dry years (Figure 1). 
Furthermore, reservoir management (abstraction rate and time, outflow by water release, including minimal outflow when relevant and connection to the stream) is also another key factor in the impacts. The large number of factors involved in the cumulative impacts makes the search for a universal indicator a never-ending quest. Instead, one research track would be to develop regional indicators based on regional analysis of the cumulative impacts. Within areas of homogeneous hydrology, soil occupation, and standardized water management operations, indicators of reservoir network properties may be more relevant than at the global scale. Following this approach, Hughes and Mantel (2010) proposed and explored for a few catchments the relevancy of an indicator integrating the annual water demand for small reservoirs, a measure of stream flow temporal variability and the mean contributing area of reservoirs. They found a correlation between the indicator and the annual mean flow decrease. Another important point would also be to differentiate between exploited and non-exploited reservoirs, considering the role of reservoir management on the impacts.

\section{Conclusion}

In this study, we investigated the cumulative impacts of small reservoirs on water resources from a quantitative aspect only. Although the reviewed studies agree that the main impacts of small reservoirs are a decrease in the river discharges and peak flow due to water abstraction from the reservoirs and water loses, the intensity of this decrease can vary considerably and is not easy to anticipate with various types of indicators. Impacts on low flow and river regime can vary from basin to basin due to the many types of reservoirs and their different uses. It was shown that a key issue with studying the cumulative impacts of small reservoirs is the lack of data on the properties and usage of the small reservoirs, which leads the various studies to adapt their strategy to address this ill-defined problem by using assumptions to simplify the estimation of these characteristics.

However, this review focused only on some aspects of the impacts of small reservoirs. Indeed, the numerous small reservoirs also impact sediment transfer, hydromorphology, biodiversity, and biochemistry. Although the literature on such topics associated with small reservoirs is not vast, these aspects were reviewed by Carluer et al. (2016). From this review, it appears that a fine spatial and temporal estimation of the hydrological impact may be required to assess these other impacts. The lack of data on some characteristics of the small reservoirs is also challenging. Even 
with such difficulties, it is assumed that small reservoirs have a large impact on sediment trapping (Yang et al., 2011) and river channel (Petts and Gurnell, 2005). The impacts on some biochemical components can accumulate according to the discontinuity distance (Bergkamp et al., 2000). The impacts on biodiversity (especially fishes) from large reservoirs are rather well known (Poff and Zimmerman, 2010); thus, the question is now how to reduce the major impacts by removing the most impacting reservoirs (Poff and Hart, 2002; Doyle et al., 2005; Grantham et al., 2014). There is no doubt that the question of removing small reservoirs should also be extended to attempt to reduce the other types of impacts, including quantitative hydrological impacts.

Socioeconomic impacts are also very important to consider since it is often the key driver to build reservoirs. It was shown in India that large reservoirs can have some drawbacks for the neighbouring population (Duflo and Pande, 2007). However, this impact can be reduced by the presence of small reservoirs that are having positive socioeconomic impacts on the local population (Blanc and Strobl, 2013; Acheampong et al., 2014). Lasage et al. (2015), for instance, focus on the social benefit of small sand reservoirs to secure water access in the context of climate change.

Indeed, it is rather important to consider the long-lasting life of the reservoir (more than 50 years) since this means an impact in the long term, but also within a changing climate. As stated in the introduction, there is increasing pressure to build reservoirs, partly to adapt to climate change. The global impacts of small reservoirs on hydrology are already estimated to be $5 \%$ of the mean discharge and $44 \%$ of the low flow (Wisser et al., 2010), although the impacts can vary in space and season (Wanders and Wada, 2015). Moreover, there is an increasing number of studies that show that water management can aggravate the duration of droughts, particularly where the development of water use was not controlled and for longer droughts (Van Loon et al., 2016; He et al., 2017; Lin et al., 2017). It is thus important to integrate in new projects the cumulative impacts of the reservoir network in the basin, as well as its ability to evolve in time according to the hydrologic conditions due to global change.

\section{Acknowledgments}

The article is one of the outcomes of the joint scientific assessment requested by the French Ministry of the Environment, Energy and Marine Affairs about information, knowledge and tools to assess the cumulative impacts of small reservoirs. The assessment was supported by Onema, 
Table A.1:

707 now AFB (French Agency of Biodiversity), and conducted by Irstea, in partnership with INRA.

708 We would like to thank all scientific colleagues who took part in the assessment, and also all 709 stakeholders and water managers who shared questions and information during meetings and 710 field visits. Particular thanks are due to Beatrice Leblanc for her efficiency as study coordina711 tor of this joint scientific assessment and to Bénédicte Augeard (ONEMA) for her wise advice 712 throughout this work. Steering committee members are also thanked for accompanying this 713 study.

714 AppendixA. 


\begin{tabular}{|c|c|c|c|c|c|c|c|c|c|c|c|}
\hline Ref & Basin & $\mathbf{A}$ & $\mathbf{L U}$ & Dam & $\mathbf{P}$ & PET & $\mathbf{Q}$ & VD & ND & $\mathbf{M}$ & Impact \\
\hline \multicolumn{12}{|c|}{ CHECK DAMS } \\
\hline $\begin{array}{l}\text { Martinez Alvarez } \\
\text { et al. (2007) }\end{array}$ & $\begin{array}{l}\text { ESP, Sierra } \\
\text { Gador }\end{array}$ & 320 & $\begin{array}{l}\text { Low vege- } \\
\text { tation }\end{array}$ & CD & 400 & 900 & 9.3 & 0.6 & 0.3 & A & $\begin{array}{l}\text { Increase } \\
\text { groundwater } \\
\text { recharge }\end{array}$ \\
\hline Xu et al. (2013) & CHN, Yanhe & 7725 & Grassland & $\mathrm{CD}$ & 505 & & & & 0.8 & $\begin{array}{l}\text { OBS } \\
\text { natm }\end{array}$ & $\begin{array}{l}-14.3 \% \mathrm{AD}+ \\
\text { erosion impact }\end{array}$ \\
\hline \multicolumn{12}{|c|}{ FLOOD CONTROL DAMS } \\
\hline $\begin{array}{l}\text { Ayalew et al. } \\
(2017)\end{array}$ & $\begin{array}{l}\text { USA, Soap } \\
\mathrm{Ck}\end{array}$ & 660 & & $\begin{array}{l}\text { FL,FI, } \\
\text { LS, } \\
\text { FP }\end{array}$ & & & & 62 & 0.2 & $\mathrm{D}$ & $\begin{array}{l}\text { Reduce peak } \\
\text { flow by } 20 \% \text { to } \\
70 \%\end{array}$ \\
\hline Frickel (1972) & $\begin{array}{l}\text { USA, } \\
\text { Willow Ck }\end{array}$ & 1400 & $\begin{array}{l}\text { Grazing, } \\
\text { conserva- } \\
\text { tion, } \\
\text { farming }\end{array}$ & FL & 320 & & & 42 & 0.1 & Obs & $\begin{array}{l}-18 \% \mathrm{AD}+ \\
\text { reduction of peak } \\
\text { discharge }\end{array}$ \\
\hline Kennon (1966) & $\begin{array}{l}\text { USA, Sand- } \\
\text { stone Ck }\end{array}$ & 221 & $\begin{array}{l}3 / 4 \text { grass- } \\
\text { land, } 1 / 4 \\
\text { cropland }\end{array}$ & $\begin{array}{l}\text { FL, } \\
\text { LS }\end{array}$ & 635 & & 76 & 120 & 0.1 & Obs & $-12 \% \mathrm{AD}$ \\
\hline $\begin{array}{l}\text { Ramireddygari et } \\
\text { al. (2000) }\end{array}$ & $\begin{array}{l}\text { USA, Wet } \\
\text { Walnut Ck }\end{array}$ & 4100 & $\begin{array}{l}65 \% \\
\text { cropland }\end{array}$ & FL, I & 510 & & 108 & & & A & $\begin{array}{l}\text { Decrease in } \\
\text { runoff and } \\
\text { piezometric level }\end{array}$ \\
\hline \multicolumn{12}{|c|}{ FARM DAM: a) Approaches based on observations } \\
\hline $\begin{array}{l}\text { Carvajal et al. } \\
\text { (2014) }\end{array}$ & $\begin{array}{l}\text { ESP, } \\
\text { Alméria }\end{array}$ & 7 & & I & 250 & & & 68 & 39.5 & WB & $\begin{array}{l}\text { Collecting } \\
\text { rainwater from } \\
\text { the roofs of the } \\
\text { greenhouses and } \\
\text { covering small } \\
\text { dams could } \\
\text { reduce external } \\
\text { water needs by } \\
53 \% \text {. }\end{array}$ \\
\hline $\begin{array}{l}\text { Martinez Alvarez } \\
\text { et al. (2008) }\end{array}$ & ESP, Segura & 3774 & & I & & 1850 & 170 & 78 & 3.7 & WB & $\begin{array}{l}\text { Regional } \\
\text { evaporation } \\
\text { losses of small } \\
\text { dams represents } \\
27 \% \text { of the } \\
\text { domestic water } \\
\text { use in a } 2 \text { million } \\
\text { inhabitants } \\
\text { region }\end{array}$ \\
\hline Culler (1961) & $\begin{array}{l}\text { USA, } \\
\text { Cheyenne }\end{array}$ & 23569 & $\begin{array}{l}\text { Grazing, } \\
\text { sagebrush }\end{array}$ & LS & 366 & & 4. & 3.2 & 0.4 & Obs & $-26 \% \mathrm{AD}$ \\
\hline $\begin{array}{l}\text { Dubreuil and } \\
\text { Girard (1973) }\end{array}$ & BRA, Sitia & 1790 & & I & 700 & 2100 & 72 & 34 & & Obs & $\begin{array}{l}-11 \% \text { to }-24 \% \\
\mathrm{AD}\end{array}$ \\
\hline \multirow{2}{*}{$\begin{array}{l}\text { Galea et al. } \\
(2005)\end{array}$} & $\begin{array}{l}\text { FRA, } \\
\text { Séoune }\end{array}$ & 463 & & I & & & & 14 & 0.3 & $\begin{array}{l}\text { Obs } \\
\text { stat }\end{array}$ & $\begin{array}{l}\text { Winter flow } \\
\text { reduced by } 31 \%\end{array}$ \\
\hline & FRA, Tescou & 287 & & I & & & & 15 & 0.6 & $\begin{array}{l}\text { Obs } \\
\text { stat }\end{array}$ & $\begin{array}{l}\text { Winter flow } \\
\text { reduced by } 42 \%\end{array}$ \\
\hline \multirow[t]{2}{*}{$\begin{array}{l}\text { Schreider et al. } \\
(2002)\end{array}$} & $\begin{array}{l}\text { AUS, Yass } \\
\text { R. }\end{array}$ & 388 & & I,LS & & & 53.1 & 17 & 5.8 & & $\begin{array}{l}-9.5 \% \mathrm{AD} ; 1 \mathrm{Ml} \\
\text { increase in farm } \\
\text { dam storage } \\
\text { corresponded to a } \\
2 \text { to } 3 \mathrm{Ml} \\
\text { decrease in } \\
\text { streamflow } \\
\text { annual yield }\end{array}$ \\
\hline & $\begin{array}{l}\text { AUS, } \\
\text { Broadwater } \\
\text { CK }\end{array}$ & 108 & & I,LS & & & 55.5 & 33 & 3.5 & & $-8.3 \% \mathrm{AD}$ \\
\hline Thompson (2012) & $\begin{array}{l}\text { NZL, upper } \\
\text { Tupiko R }\end{array}$ & 0.7 & & LS & $\begin{array}{c}656 . \\
5\end{array}$ & 653 & 216 & 16.6 & 4.3 & $\begin{array}{l}\text { Obs } \\
\text { Pair }\end{array}$ & $\begin{array}{l}-40 \% \mathrm{AD}+ \\
\text { change in flow } \\
\text { regime }\end{array}$ \\
\hline
\end{tabular}

Table A.1 continnue on next page 


\begin{tabular}{|c|c|c|c|c|c|c|c|c|c|c|c|}
\hline \multicolumn{12}{|c|}{ FARM DAMS: b) Approaches based on aggregated model } \\
\hline \multirow{6}{*}{$\begin{array}{l}\text { Hughes and } \\
\text { Mantel (2010) }\end{array}$} & $\begin{array}{l}\text { ZAF, H10A } \\
\text { Bread R. }\end{array}$ & 234 & $\begin{array}{l}\text { Deciduous } \\
\text { fruit } \\
\text { orchards }\end{array}$ & $\mathrm{I}, \mathrm{LS}$ & \multirow{4}{*}{$\begin{array}{l}500 \\
\text { to } 1 \\
000\end{array}$} & \multirow{4}{*}{1650} & 154 & 0.1 & 0.6 & A & $-17 \% \mathrm{AD}$ \\
\hline & $\begin{array}{l}\text { ZAF, H10B } \\
\text { Bread R }\end{array}$ & 162 & $\begin{array}{l}\text { Deciduous } \\
\text { fruit } \\
\text { orchards }\end{array}$ & I,LS & & & 273 & 0.1 & 0.5 & A & $-21.5 \% \mathrm{AD}$ \\
\hline & $\begin{array}{l}\text { ZAF, H10C } \\
\text { Bread R }\end{array}$ & 260 & $\begin{array}{l}\text { Deciduous } \\
\text { fruit } \\
\text { orchards }\end{array}$ & I,LS & & & 564 & 0.1 & 0.8 & A & $-27 \% \mathrm{AD}$ \\
\hline & $\begin{array}{l}\text { ZAF, H10D } \\
\text { Bread R }\end{array}$ & 97 & $\begin{array}{l}\text { Deciduous } \\
\text { fruit } \\
\text { orchards }\end{array}$ & I,LS & & & 2054 & & & A & $18 \% \mathrm{AD}$ \\
\hline & ZAF, X21F & 397 & $\begin{array}{l}\text { Stock } \\
\text { grazing }\end{array}$ & I,LS & 760 & 1400 & 109 & 0.02 & 0.5 & A & $-16 \% \mathrm{AD}$ \\
\hline & ZAF, D52A & 378 & $\begin{array}{l}\text { Stock } \\
\text { grazing }\end{array}$ & $\mathrm{I}, \mathrm{LS}$ & 320 & 1900 & 13 & 0.02 & 0.1 & A & $-35 \%$ \\
\hline $\begin{array}{l}\text { Perrin et al. } \\
(2012)\end{array}$ & IND, Gawel & 84 & $\begin{array}{l}\text { Semi-arid } \\
\text { scrubland, } \\
\text { rainfed } \\
\text { crop, } \\
\text { irrigated } \\
\text { rice }\end{array}$ & I & 812 & 1800 & & & & A & $\begin{array}{l}\text { Evaporation loss } \\
\text { is dominant. } \\
\text { Tank infiltration } \\
\text { represents } 43 \% \\
\text { of the } \\
\text { groundwater } \\
\text { recharge on } \\
\text { average, } 54 \% \\
\text { AD during dry } \\
\text { year and } 32 \% \\
\text { AD during wet } \\
\text { year }\end{array}$ \\
\hline $\begin{array}{l}\text { Tarboton and } \\
\text { Schulze (1991) } \\
\end{array}$ & \begin{tabular}{|l|} 
ZAF, \\
Midmar
\end{tabular} & 912 & & & 952 & & 110 & & & A & $-6 \% \mathrm{AD}$ \\
\hline $\begin{array}{l}\text { Habets et al. } \\
\text { (2014) }\end{array}$ & FRA, Layon & 930 & $\begin{array}{l}\text { Maize, } \\
\text { vineyards }\end{array}$ & I & 660 & & 1475 & 1.5 & 1.4 & $\mathrm{Ag}$ & $-9 \% \mathrm{AD}$ \\
\hline \multirow{3}{*}{ Meigh (1995) } & $\begin{array}{l}\text { BWA, } \\
\text { Garo-bone } \\
\end{array}$ & 3983 & & \multirow{3}{*}{ I,DW } & \multirow{3}{*}{500} & \multirow{3}{*}{2000} & 7.6 & 6.5 & 0.05 & As & $-25 \% \mathrm{AD}$ \\
\hline & \begin{tabular}{|l|} 
BWA, \\
Bokaa \\
\end{tabular} & 3570 & & & & & 3.7 & 1 & 0.03 & As & $-13 \% \mathrm{AD}$ \\
\hline & \begin{tabular}{|l|} 
BWA, \\
Shashe \\
\end{tabular} & 3650 & & & & & 29 & 0.04 & 0.004 & As & $-0.2 \% \mathrm{AD}$ \\
\hline O'Connor (2001) & $\begin{array}{l}\text { ZAF, } \\
\text { Limpopo R. } \\
\text { Kolope- } \\
\text { Setonki sub- } \\
\text { basin }\end{array}$ & 1992 & $\begin{array}{l}\text { Riparian } \\
\text { woodland }\end{array}$ & & 377 & 2050 & 3.5 & & 0.04 & Anat & $\begin{array}{l}\text { The many small } \\
\text { farm dams } \\
\text { reduce flow } \\
\text { during critical } \\
\text { dry years to } \\
\text { levels causing } \\
\text { dieback of some } \\
\text { vegetation }\end{array}$ \\
\hline \multicolumn{12}{|c|}{ FARM DAMS: c) Approaches based on statistical model } \\
\hline Cetin et al. (2009) & \begin{tabular}{|l} 
AUS, \\
Campapse R.
\end{tabular} & 4000 & & LS, I & & 1350 & 74. & 11 & 3.2 & S & $7 \%$ \\
\hline $\begin{array}{l}\text { Fowlert et al. } \\
\text { (2015) }\end{array}$ & \begin{tabular}{|l} 
AUS, \\
Stringybark \\
Ck
\end{tabular} & 73 & & & $\begin{array}{c}1 \\
050\end{array}$ & & 116 & 43.2 & 7.7 & $\mathrm{~S}$ & $-22 \% \mathrm{AD}$ \\
\hline $\begin{array}{l}\text { Güntner et al. } \\
\text { (2004) }\end{array}$ & $\begin{array}{l}\text { BRA, Upper } \\
\text { Jaguaribe }\end{array}$ & 24200 & $\begin{array}{l}\text { Wood- } \\
\text { land, cattle } \\
\text { farming } \\
\text { crops } \\
\text { (bean, } \\
\text { maize) }\end{array}$ & I & 700 & 2300 & 285 & & 0.2 & $\mathrm{~S}$ & $-21 \% \mathrm{AD}$ \\
\hline $\begin{array}{l}\text { Nathan et al. } \\
(2005)\end{array}$ & $\begin{array}{l}\text { AUS, Avoca } \\
\text { R. }\end{array}$ & 77 & Grazing & $\mathrm{I}, \mathrm{LS}$ & 580 & & 70 & 6.7 & 2.8 & $\mathrm{~S} \backslash$ & $\begin{array}{l}\text { The natural flow } \\
\text { is closed to the } \\
\text { observed one and } \\
\text { there is small }\end{array}$ \\
\hline
\end{tabular}

Table A.1 continnue on next page 


\begin{tabular}{|c|c|c|c|c|c|c|c|c|c|c|c|}
\hline & & & & & & & & & & & $\begin{array}{l}\text { differences } \\
\text { between } \\
\text { distributed and } \\
\text { statistical } \\
\text { modelings }\end{array}$ \\
\hline & $\begin{array}{l}\text { AUS, } \\
\text { Woollen } \\
\text { Creek }\end{array}$ & 11 & $\begin{array}{l}\text { Grazing } \\
\text { and broad- } \\
\text { acre crops }\end{array}$ & & 930 & & 66 & 40.1 & 10.8 & $\mathrm{~S}$ & \multirow{2}{*}{$\begin{array}{l}\text { The natural flow } \\
\text { is underestimated } \\
\text { by the statistical } \\
\text { model compared } \\
\text { to the distributed } \\
\text { model, which } \\
\text { lead to } \\
\text { underestimation } \\
\text { of the impact of } \\
\text { small dams by a } \\
\text { factor of } 2 \text {. }\end{array}$} \\
\hline & $\begin{array}{l}\text { AUS, Lens- } \\
\text { wood creek }\end{array}$ & 28 & $\begin{array}{l}\text { Agri- } \\
\text { culture } \\
\text { dairy } \\
\text { production }\end{array}$ & I,LS & $\begin{array}{c}1 \\
030\end{array}$ & & 230 & 36.8 & 7.9 & $\mathrm{~s}$ & \\
\hline \multirow{5}{*}{ Neal et al. (2000) } & $\begin{array}{l}\text { AUS, Ten } \\
\text { Mile Ck }\end{array}$ & 46 & & \multirow{5}{*}{ I,LS } & & & 178 & & & S & $-0.7 \% \mathrm{AD}$ \\
\hline & $\begin{array}{l}\text { AUS, } \\
\text { Arthues Ck }\end{array}$ & 105 & & & & & 96 & & & $\mathrm{~S}$ & $-3.1 \% \mathrm{AD}$ \\
\hline & $\begin{array}{l}\text { AUS, Mont } \\
\text { Cole Ck }\end{array}$ & 158 & & & & & 102 & & & $\mathrm{~S}$ & $-4.8 \% \mathrm{AD}$ \\
\hline & $\begin{array}{l}\text { AUS, } \\
\text { Running Ck }\end{array}$ & 126 & & & & & 291 & & & $\mathrm{~S}$ & $-0.6 \% \mathrm{AD}$ \\
\hline & $\begin{array}{l}\text { AUS, Woori } \\
\text { Yallock Ck }\end{array}$ & 322 & & & & & 293 & & & $\mathrm{~S}$ & $-1.5 \% \mathrm{AD}$ \\
\hline $\begin{array}{l}\text { Malveira et al. } \\
(2012)\end{array}$ & $\begin{array}{l}\text { BRA, Upper } \\
\text { Jaguaribe }\end{array}$ & 24200 & & I,DW & 700 & 2300 & 66 & $\begin{array}{c}589 . \\
2 \\
\end{array}$ & 0.16 & $\mathrm{~S}$ & \\
\hline Teoh (2003) & $\begin{array}{l}\text { AUS, } \\
\text { Onkaparinga }\end{array}$ & 560 & & & 770 & 1560 & 134 & 15 & 4.8 & $\mathrm{~S}$ & $-8 \% \mathrm{AD}$ \\
\hline \multirow{2}{*}{ Thompson (2012) } & $\begin{array}{l}\text { NZL, upper } \\
\text { Tupiko }\end{array}$ & 85 & & \multirow{2}{*}{ LS,I } & $\begin{array}{c}1 \\
428 \\
\end{array}$ & 653 & 568 & 8 & 5.3 & $\mathrm{~S}$ & $-1.1 \% \mathrm{AD}$ \\
\hline & $\begin{array}{l}\text { NZL, upper } \\
\text { Tukituki }\end{array}$ & 740 & & & 849 & 653 & 6450 & 6.5 & 2.9 & $\mathrm{~S}$ & $-0.9 \% \mathrm{AD}$ \\
\hline \multicolumn{12}{|c|}{ FARM DAMS: d) Approaches based on distributed model } \\
\hline $\begin{array}{l}\text { Deitch et al. } \\
\text { (2013) }\end{array}$ & $\begin{array}{l}\text { USA, } \\
\text { Russian R. }\end{array}$ & 743 & $\begin{array}{l}\text { Mostly } \\
\text { vineyard }\end{array}$ & & & & & 6.7 & 0.6 & $\mathrm{D}$ & $\begin{array}{l}\text { More than } 25 \% \\
\text { of the drainage } \\
\text { network below } \\
\text { reservoirs is } \\
\text { impaired by over } \\
50 \% \text {. Impacts are } \\
\text { more important } \\
\text { for early season } \\
\text { flow and } \\
\text { upstream basin }\end{array}$ \\
\hline $\begin{array}{l}\text { Shinogi et al. } \\
\text { (1998) }\end{array}$ & $\begin{array}{l}\text { LKA, Tirra- } \\
\text { pane }\end{array}$ & 10 & & I & $\begin{array}{c}1 \\
491\end{array}$ & 2445 & & & & $\mathrm{D}$ & $\begin{array}{l}\text { Irrigation is } 11 \% \\
\text { of inflow, } \\
\text { seepage and } \\
\text { evaporation } \\
\text { losses } 28.5 \%\end{array}$ \\
\hline
\end{tabular}

Table A.1 Some insights on the references that address the cumulative impacts of small dams on water resources: Ref: references; Basin: country code and name of the basin; A: area of the basin in $\mathrm{km}^{2}$; LU: land use; Dam: type of dam; P: mean annual precipitation (mm/year); PET: mean annual potential evapotranspiration ( $\mathrm{mm} /$ year); Q: mean annual river flow (mm/year); VD: volume density of the dams in $1000 \mathrm{~m}^{3} / \mathrm{km}^{2}$; ND: density of dams expressed as number per square kilometre; M: method used for the study; Impact: reported impact. Abbreviations for methods: A: Aggregated modelisation; Ag: aggregated on grid; As: aggregated on sub-catchment; D: distributed modelisation; S: statistical modelisation; OBS: direct observation; OBS\&nat m: observation of river flow associated with natural modelling (without dams); WB: water balance approach; OBS stat: statistical analysis of observed river flow; OBS Pair: pair catchment experiment; Abbreviations for dam use: CD: check dam (erosion); FI: fire protection; FL: flood control; FP: fish pond; LS: livestock; I: irrigation; DW: drinking water; Abbreviation for impact: AD: annual discharge 
References

Acheampong EN, Ozor N, Sekyi-Annan E (2014) Development of small dams and their impact on livelihoods: Cases from northern ghana. African Journal of Agricultural Research 9(24):1867-1877

Alonso E, Degoutte G, Girard H (1990) Results of seventeen years of using geomembranes in dams and basins. In: Proceedings of the 4th International conference on geotextiles, geomembranes and related products, pp 437-442

Anderson E (1954) Energy-budget studies, water-loss investigations: Lake hefnor studies. Professional Paper 269

Antonino ACD, Hammecker C, Montenegro S, Netto AM, Angulo-Jaramillo R, Lira C (2005) Subirrigation of land bordering small reservoirs in the semi-arid region in the northeast of brazil: monitoring and water balance. Agricultural Water Management 73(2):131-147, DOI 10.1016/j.agwat.2004.10.001

Assouline S, Tyler S, Tanny J, Cohen S, Bou-Zeid E, Parlange M, Katul G (2008) Evaporation from three water bodies of different sizes and climates: Measurements and scaling analysis. Advances in Water Resources 31(1):160-172

Assouline S, Narkis K, Or D (2011) Evaporation suppression from water reservoirs: Efficiency considerations of partial covers. Water Resources Research 47(7):n/a-n/a, DOI 10.1029/2010wr009889

Ayalew TB, Krajewski WF, Mantilla R, Wright DB, Small SJ (2017) Effect of spatially distributed small dams on flood frequency: Insights from the soap creek watershed. Journal of Hydrologic Engineering 22(7):04017,011

Barber ME, Hossain A, Covert JJ, Gregory GJ (2009) Augmentation of seasonal low stream flows by artificial recharge in the spokane valley-rathdrum prairie aquifer of idaho and washington, usa. Hydrogeology journal 17(6):1459-1470

Barnes GT (2008) The potential for monolayers to reduce the evaporation of water from large water storages. Agricultural Water Management 95(4):339-353, DOI 10.1016/j.agwat.2007.12.003

Bartout P, Touchart L, Terasmaa J, Choffel Q, Marzecova A, Koff T, Kapanen G, Qsair Z, Maleval V, Millot C, et al. (2015) A new approach to inventorying bodies of water, from local to global scale. DIE ERDE-Journal of the Geographical Society of Berlin 146(4):245-258

Benzaghta MA, Mohamad TA (2009) Evaporation from reservoir and reduction methods: An overview and assessment study. In: International Engineering Convention, Kingdom of Saudi Arabia, p 9p

Berg MD, Popescu SC, Wilcox BP, Angerer JP, Rhodes EC, McAlister J, Fox WE (2016) Small farm ponds: overlooked features with important impacts on watershed sediment transport. Journal of the American Water Resources Association 52(1):67-76

Bergkamp G, McCartney M, Dugan P, McNeely J, Acreman M (2000) Dams, ecosystem functions and environmental restoration. Thematic review II 1:1-187

Biemans H, Haddeland I, Kabat P, Ludwig F, Hutjes R, Heinke J, Von Bloh W, Gerten D (2011) Impact of reservoirs on river discharge and irrigation water supply during the 20th century. Water Resources Research 47(3)

Blanc E, Strobl E (2013) Is small better? a comparison of the effect of large and small dams on cropland productivity in south africa. The World Bank Economic Review 28(3):545-576

Boisson A, Baisset M, Alazard M, Perrin J, Villesseche D, Dewandel B, Kloppmann W, Chandra S, Picot-Colbeaux G, Sarah S, Ahmed S, Marechal JC (2014) Comparison of surface and groundwater balance approaches in the evaluation of managed aquifer recharge structures: Case of a percolation tank in a crystalline aquifer in india. Journal of Hydrology 519:1620-1633, DOI 10.1016/j.jhydrol.2014.09.022

Bouteffeha M, Dages C, Bouhlila R, Molenat J (2015) A water balance approach for quantifying subsurface exchange fluxes and associated errors in hill reservoirs in semiarid regions. Hydrological Processes 29(7):1861-1872

Brown AE, Zhang L, McMahon TA, Western AW, Vertessy RA (2005) A review of paired catchment studies for determining changes in water yield resulting from alterations in vegetation. Journal of Hydrology 310(1-4):28 - 61, DOI http://dx.doi.org/10.1016/j.jhydrol.2004.12.010

de Bruin HAR (1978) A simple model for shallow lake evaporation. Journal of Applied Meteorology 17(8):1132-1134, DOI 10.1175/1520-0450(1978)017;1132:asmfsli2.0.co;2

Camnasio E, Becciu G (2011) Evaluation of the feasibility of irrigation storage in a flood detention pond in an agricultural catchment in northern italy. Water resources management 25(5):1489-1508

Canter LW, Kamath J (1995) Questionnaire checklist for cumulative impacts. Environmental Impact Assessment Review 15(4):311-339

Carluer N, Babut M, Belliard J, Bernez I, Burger-Leenhardt D, Dorioz J, Douez O, Dufour D, Grimaldi C, Habets F, Le Bissonnais Y, Molénat J, Rollet A, Rosset V, Sauvage S, Usseglio-Polatera P, Leblanc B (2016) Cumulative impact of reservoirs on the aquatic environment. joint scientific assessment summary. Tech. rep., DOI http://dx.doi.org/10.14758/SCIENT.ASSESMENT.REPORT.05.2016, URL https://expertise-impact-cumuleretenues.irstea.fr/wp-content/uploads/2016/05/Summary-report-Cumulative-impact-of-reservoirs-on-the-aquaticenvironmentBibliographical-references.pdf

Carvajal F, Agüera F, Sánchez-Hermosilla J (2014) Water balance in artificial on-farm agricultural water reservoirs for the irrigation of intensive greenhouse crops. Agricultural Water Management 131:146-155, DOI 10.1016/j.agwat.2013.09.006

Cetin L, Freebairn A, Jordan P, Huider B (2009) A model for assessing the impacts of farm dams on surface waters in 
the watercast catchment modelling framework. Modelling and Simulation Society of Australia and New Zealand and International Association for Mathematics and Computers in Simulation, Cairns, Australia, pp 3478-3484

Chao BF, Wu YH, Li YS (2008) Impact of artificial reservoir water impoundment on global sea level. Science 320(5873):212-214, DOI 10.1126/science.1154580

Craig IP (2008) Loss of storage water through evaporation with particular reference to arid and semi-arid zone pastoralism in australia. Report, NCEA publication,University of Southern Queensland, Australia

Cresswell D (1991) Integrated management of farm dams in the Barossa Valley. Engineering and Water Supply Dept (Adelaide, Australia)

Culler RC (1961) Hydrology of the upper cheyenne river basin. Report Water Supply paper 1531, US Geological Survey

Deitch MJ, Merenlender AM, Feirer S (2013) Cumulative effects of small reservoirs on streamflow in northern coastal california catchments. Water Resources Management 27(15):5101-5118, DOI 10.1007/s11269-013-0455-4

Del Giudice G, Rasulo G, Siciliano D, Padulano R (2014) Combined effects of parallel and series detention basins for flood peak reduction. Water resources management 28(10):3193-3205

Downing Ja (2010) Emerging global role of small lakes and ponds: little things mean a lot. Limnetica 29(1):9-24

Doyle MW, Stanley EH, Orr CH, Selle AR, Sethi SA, Harbor JM (2005) Stream ecosystem response to small dam removal: lessons from the heartland. Geomorphology 71(1):227-244

Dubreuil P, Girard G (1973) Influence of a Very Large Number of Small Reservoirs on the annual Flow Regime of a Tropical Stream, American Geophysical Union, pp 295-299. DOI 10.1029/GM017p0295

Dubreuil P, Girard G, Herbaud J (1968) Monographie hvdrologique du bassin de Jaguaribe. Tech. rep., ORSTOM, URL http://horizon.documentation.ird.fr/exl-doc/pleins_textes/pleins_textes_6/Mem_cm/12992.pdf

Duflo E, Pande R (2007) Dams. The Quarterly Journal of Economics 122(2):601-646

Fennessey LA, Hamlett JM, Aron G, LaSota D (2001) Changes in runoff due to stormwater management pond regulations. Journal of Hydrologic Engineering 6(4):317-327

Fernández M, González A, Carreño J, Perez C, Bonachela S (2007) Analysis of on-farm irrigation performance in mediterranean greenhouses. Agricultural water management 89(3):251-260

Fowe T, Karambiri H, Paturel JE, Poussin JC, Cecchi P (2015) Water balance of small reservoirs in the volta basin: A case study of boura reservoir in burkina faso. Agricultural Water Management 152:99-109, DOI 10.1016/j.agwat.2015.01.006

Fowler K, Morden R, et al. (2009) Investigation of strategies for targeting dams for low flow bypasses. In: H2009: 32nd Hydrology and Water Resources Symposium, Newcastle: Adapting to Change, Barton, A.C.T.: Engineers Australia, pp 1185-1193

Fowler K, Donohue R, Morden R, Durrant J, Hall J (2012) Decision support and uncertainty in self-supply irrigation areas. In: Proceedings of the Australian Hydrology and Water Resources Symposium, Barton, ACT: Engineers Australia, Sydney, pp 93-101

Fowler K, Morden R, Lowe L, Nathan R (2015) Advances in assessing the impact of hillside farm dams on streamflow. Australian Journal of Water Resources 19(2):96-108

Frickel DG (1972) Hydrology and effects of conservation structures, willow creek basin, valley county, montana 19541968. Tech. Rep. Water-Supply Paper 1532-G, US Geological Survey

Gal L, Grippa M, Hiernaux P, Peugeot C, Mougin E, Kergoat L (2016) Changes in lakes water volume and runoff over ungauged sahelian watersheds. Journal of Hydrology 540:1176-1188, DOI http://dx.doi.org/10.1016/j.jhydrol.2016.07.035

Galea B, Vasquez-Paulus B, Renard B, Breil P (2005) L'impact des prélèvements d'eau pour l'irrigation sur les régimes hydrologiques des sous-bassins du tescou et de la séoune (bassin adour-garonne, france) / the water withdrawn from tescou and seoune rivers for irrigation, its consequences on the hydrological regime of the sub-basins (adour-garonne watershed, france). Revue des Sciences de l'Eau/Journal of Water Science 18(3):273-305, DOI 10.7202/705560ar

Gallego-Elvira B, Baille a, Martín-Górriz B, Martínez-Álvarez V (2010) Energy balance and evaporation loss of an agricultural reservoir in a semi-arid climate (south-eastern spain). Hydrological Processes 24(December 2009):758766, DOI 10.1002/hyp.7520

Gallego-Elvira B, Baille A, Martin-Gorriz B, Maestre-Valero JF, Martínez-Alvarez V (2011) Energy balance and evaporation loss of an irrigation reservoir equipped with a suspended cover in a semiarid climate (south-eastern spain). Hydrological Processes 25(11):1694-1703, DOI 10.1002/hyp.7929

Girard G (1966) Estimation de l'évaporation sur les réservoirs de barrages en région intertropicale semi-aride. In: Hydrology of Lakes, Symposium of Garda, IAHS, 70, pp 233-244

Glendenning CJ, van Ogtrop FF, Mishra aK, Vervoort RW (2012) Balancing watershed and local scale impacts of rain water harvesting in india-a review. Agricultural Water Management 107:1-13, DOI 10.1016/j.agwat.2012.01.011

Güntner A, Krol MS, Araújo JCD, Bronstert A (2004) Simple water balance modelling of surface reservoir systems in a large data-scarce semiarid region/modélisation simple du bilan hydrologique de systèmes de réservoirs de surface dans une grande région semi-aride pauvre en données. Hydrological sciences journal 49(5)

Grantham TE, Viers JH, Moyle PB (2014) Systematic screening of dams for environmental flow assessment and imple- 
832 mentation. BioScience 64(11):1006-1018

833 Gutteridge-Haskins-Davey (1987) Farm dams in catchments study. Tech. Rep. 5583/01, Department of Water Resources, Victoria, Australia

35 Habets F, Philippe E, Martin E, David C, Leseur F (2014) Small farm dams: impact on river flows and sustainability in a context of climate change. Hydrol Earth Syst Sci 18:4207-4222

He X, Wada Y, Wanders N, Sheffield J (2017) Intensification of hydrological drought in california by human water management. Geophysical Research Letters 44(4):1777-1785

Hingray B, Picouet C, Musy A (2009) Hydrology: a science for engineers. CRC Press

Hughes DA, Mantel SK (2010) Estimating the uncertainty in simulating the impacts of small farm dams on streamflow regimes in south africa. Hydrological Sciences Journal-Journal Des Sciences Hydrologiques 55(4):578-592, DOI $10.1080 / 02626667.2010 .484903$

Jain A, Roy T (2017) Evaporation modelling using neural network for assessing the self-sustainability of a water body Lakes and Reservoirs 22(2):123-133, DOI 10.1111/lre.12175

Jayatilaka CJ, Sakthivadivel R, Shinogi Y, Makin IW, Witharana P (2003) A simple water balance modelling approach for determining water availability in an irrigation tank cascade system. Journal of Hydrology 273(1-4):81-102, DOI 10.1016/s0022-1694(02)00360-8

Kennon KW (1966) Hydrologic effects of small reservoirs in sandstone creek watershed. Report Water Supply paper 1839-C, US Geological Survey

Lasage R, Verburg PH (2015) Evaluation of small scale water harvesting techniques for semi-arid environments. Journal of Arid Environments 118:48-57

Lasage R, Aerts JC, Verburg PH, Sileshi AS (2015) The role of small scale sand dams in securing water supply under climate change in ethiopia. Mitigation and adaptation strategies for global change 20(2):317-339

Lin Q, Wu Z, Singh VP, Sadeghi S, He H, Lu G (2017) Correlation between hydrological drought, climatic factors, reservoir operation, and vegetation cover in the xijiang basin, south china. Journal of Hydrology 549:512-524

Lowe L, Nathan R, Morden R (2005) Assessing the impact of farm dams on streamflows, part ii: Regional characterisation. Australian Journal of Water Resources 9(1):13-26

Lund JR (2006) Drought storage allocation rules for surface reservoir systems. Journal of water resources planning and management 132(5):395-397

Magliano PN, Murray F, Baldi G, Aurand S, Páez RA, Harder W, Jobbágy EG (2015) Rainwater harvesting in dry chaco: Regional distribution and local water balance. Journal of Arid Environments 123:93-102

Malveira V, Araújo J, Güntner A (2012) Hydrological impact of a high-density reservoir network in semiarid northeastern brazil. Journal of Hydrologic Engineering 17(1):109-117, DOI doi:10.1061/(ASCE)HE.1943-5584.0000404

Martín-Rosales W, Gisbert J, Pulido-Bosch A, Vallejos A, Fernández-Cortés A (2007) Estimating groundwater recharge induced by engineering systems in a semiarid area (southeastern spain). Environmental Geology 52(5):985-995

Martínez-Alvarez V, Maestre-Valero JF (2015) Comparative analysis of on-farm reservoir management techniques and their effect on filtering requirements for irrigation. Water Resources Management 29(4):1155-1167, DOI 10.1007/s11269-014-0866-x

Martínez Alvarez V, González-Real MM, Baille A, Molina Martínez JM (2007) A novel approach for estimating the pan coefficient of irrigation water reservoirs. Agricultural Water Management 92:29-40, DOI 10.1016/j.agwat.2007.04.011

Martínez Alvarez V, González-Real MM, Baille a, Maestre Valero JF, Gallego Elvira B (2008) Regional assessment of evaporation from agricultural irrigation reservoirs in a semiarid climate. Agricultural Water Management 95(9):10561066, DOI 10.1016/j.agwat.2008.04.003

Massuel S, Perrin J, Mascre C, Mohamed W, Boisson A, Ahmed S (2014) Managed aquifer recharge in south india: What to expect from small percolation tanks in hard rock? Journal of Hydrology 512:157-167, DOI 10.1016/j.jhydro1.2014.02.062

Mbaka JG, Wanjiru Mwaniki M (2015) A global review of the downstream effects of small impoundments on stream habitat conditions and macroinvertebrates. Environmental Reviews 23(3):257-262

McCold LN, Saulsbury JW (1996) Including past and present impacts in cumulative impact assessments. Environmental management 20(5):767-776

McGloin R, McGowan H, McJannet D, Burn S (2014) Modelling sub-daily latent heat fluxes from a small reservoir. Journal of Hydrology 519:2301-2311, DOI 10.1016/j.jhydrol.2014.10.032

McJannet D, Cook F, McGloin R, McGowan H, Burn S, Sherman B (2013) Long-term energy flux measurements over an irrigation water storage using scintillometry. Agricultural and forest meteorology 168:93-107

McMahon Ta, Peel MC, Lowe L, Srikanthan R, McVicar TR (2013) Estimating actual, potential, reference crop and pan evaporation using standard meteorological data: a pragmatic synthesis. Hydrology and Earth System Sciences 17(4):1331-1363, DOI 10.5194/hess-17-1331-2013

Meigh J (1995) The impact of small farm reservoirs on urban water supplies in botswana. Natural Resources Forum 19(I):71-83 
Mengistu MG, Savage MJ (2010) Open water evaporation estimation for a small shallow reservoir in winter using surface renewal. Journal of Hydrology 380(1-2):27-35, DOI 10.1016/j.jhydrol.2009.10.014

Messager ML, Lehner B, Grill G, Nedeva I, Schmitt O (2016) Estimating the volume and age of water stored in global lakes using a geo-statistical approach. Nature communications 7:13,603

Mialhe F, Gunnell Y, Mering C (2008) Synoptic assessment of water resource variability in reservoirs by remote sensing: General approach and application to the runoff harvesting systems of south india. Water Resources Research 44(5):n/a-n/a, DOI 10.1029/2007WR006065, URL http://dx.doi.org/10.1029/2007WR006065, w05411

Molle F (1991) Caractéristiques et potentialités des" açudes" du nordeste brésilien. PhD thesis, University of Montpellier, France

Morton FI (1983) Operational estimates of lake evaporation. Journal of Hydrology 66:77-100

Nathan R, Lowe L (2012) The hydrologic impacts of farm dams. Australian Journal of Water Resources 16(1):75-83

Nathan R, Jordan P, Morden R (2005) Assessing the impact of farm dams on streamflows, part i: Development of simulation tools. Australian Journal of Water Resources 9(1):1-12

Neal BP, Shephard P, Austin KA, Nathan RJ (2000) The effect of catchment farm dams on streamflows - victorian case studies. In: Proc., Hydro 2000, 3rd International Hydrology and Water Resources Symposium, Barton, A.C.T.: Institution of Engineers, Australia, 1, pp 836-841

Nordbo A, Launiainen S, Mammarella I, Leppäranta M, Huotari J, Ojala A, Vesala T (2011) Long-term energy flux measurements and energy balance over a small boreal lake using eddy covariance technique. Journal of Geophysical Research 116(D2):D02,119-D02,119, DOI 10.1029/2010jd014542

Ockenden A, Kotwicki V (1982) The effect of farm dams on flows in the North Para River. Engineering and Water Supply Department, South Australia

O'Connor T (2001) Effect of small catchment dams on downstream vegetation of a seasonal river in semi-arid african savanna. Journal of Applied Ecology 38(6):1314-1325

Pachauri RK, Allen MR, Barros VR, Broome J, Cramer W, Christ R, Church JA, Clarke L, Dahe Q, Dasgupta P, et al. (2014) Climate change 2014: synthesis report. Contribution of Working Groups I, II and III to the fifth assessment report of the Intergovernmental Panel on Climate Change. IPCC

Payan JL, Perrin C, Andreassian V, Michel C (2008) How can man-made water reservoirs be accounted for in a lumped rainfall-runoff model? Water Resources Research 44(3), DOI 10.1029/2007wr005971

Perrin J, Ferrant S, Massuel S, Dewandel B, Maréchal JC, Aulong S, Ahmed S (2012) Assessing water availability in a semi-arid watershed of southern india using a semi-distributed model. Journal of Hydrology 460-461:143-155, DOI 10.1016/j.jhydrol.2012.07.002

Petts GE, Gurnell AM (2005) Dams and geomorphology: research progress and future directions. Geomorphology 71(1):27-47

Pisaniello JD (2010) Attitudes and policy responses to australian farm dam safety threats: comparative lessons for water resources managers. International Journal of Water Resources Development 26(3):381-402

Poff NL, Hart DD (2002) How dams vary and why it matters for the emerging science of dam removal. BioScience 52(8):659-668

Poff NL, Zimmerman JK (2010) Ecological responses to altered flow regimes: a literature review to inform the science and management of environmental flows. Freshwater Biology 55(1):194-205

Ragab R, Austin B, Moidinis D (2001) The hydromed model and its application to semi-arid mediterranean catchments with hill reservoirs 1: the rainfall-runoff model using a genetic algorithm for optimisation. Hydrology and Earth System Sciences 5(4):543-553

Ramireddygari SR, Sophocleous MA, Koelliker JK, Perkins SP, Govindaraju RS (2000) Development and application of a comprehensive simulation model to evaluate impacts of watershed structures and irrigation water use on streamflow and groundwater: the case of wet walnut creek watershed, kansas, usa. Journal of Hydrology 236:223-246, DOI 10.1016/s0022-1694(00)00295-x

Reca J, García-Manzano A, Martínez J (2015) Optimal pumping scheduling model considering reservoir evaporation. Agricultural Water Management 148:250-257

Rosenberry DO, Winter TC, Buso DC, Likens GE (2007) Comparison of 15 evaporation methods applied to a small mountain lake in the northeastern usa. Journal of Hydrology 340:149-166, DOI 10.1016/j.jhydrol.2007.03.018

Schreider SY, Jakeman aJ, Letcher Ra, Nathan RJ, Neal BP, Beavis SG (2002) Detecting changes in streamflow response to changes in non-climatic catchment conditions: farm dam development in the murray-darling basin, australia. Journal of Hydrology 262(1-4):84-98, DOI 10.1016/s0022-1694(02)00023-9

Shinde MG, Gorantiwar S, Smout IK (2010) Application of watershed-based tank system model for rainwater harvesting and irrigation in india. Journal of Irrigation and Drainage Engineering 137(10):659-667

Shinogi Y, Makin IW, Witharana P (1998) Simulation of the water balance in a dry zone tank cascade. In: National Conference of The status and Future Direction of Water Research in Sri Lanka

Siderius C, Boonstra H, Munaswamy V, Ramana C, Kabat P, van Ierland E, Hellegers P (2015) Climate-smart tank irrigation: A multi-year analysis of improved conjunctive water use under high rainfall variability. Agricultural Water 


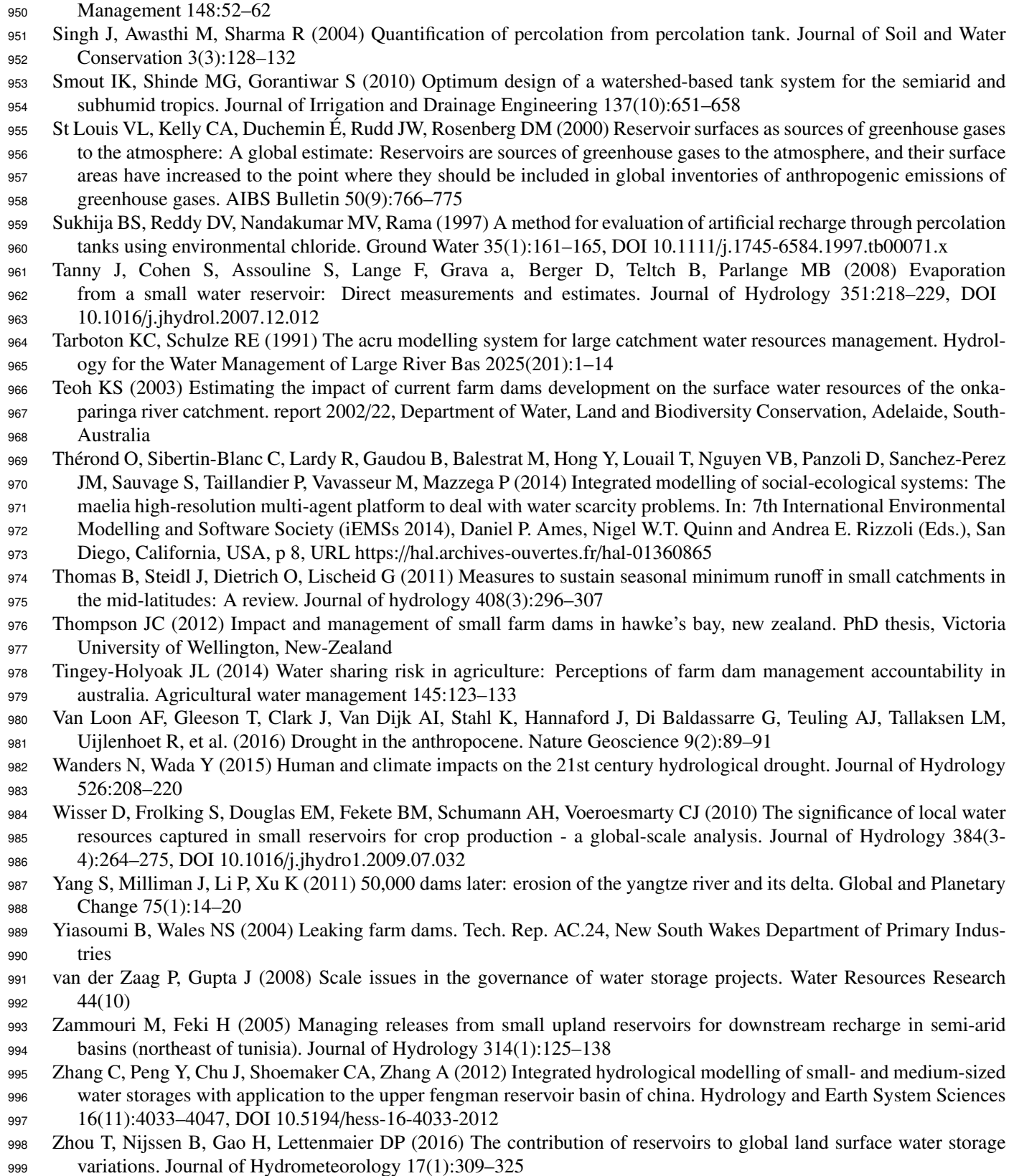

